\title{
Dyrenes betydning i religion og filosofi - en oversigt
}

\author{
LARS ALBINUS
}

ENGLISH ABSTRACT: In this article, I present an overview of the meaning and significance of animals in a religious context, ranging from tribal cultures to a Christian tradition. Furthermore, I will draw a line to current philosophical and eco-critical debates. My thesis is that in many cultures humans have had a tendency to regard animals as a mediating link between life in this world and a transcendent form of being. In animistic and totemistic ontologies animals are closely related to divinities as well as to humanity as such, whereas in more developed forms of religion they become part of a hierarchy as mediators between humans and gods. This is seen, for instance, in sacrificial cults. Later their significance decreases according to their predominant role of being moral similes. In our own times, however, animals seem to regain a significance as beings in their own right owing to our increasing ecological awareness. Prominent philosophers such as Derrida and Agamben have thus questioned the traditional view of human exceptionalism and opened up for a new understanding of the relationship between being animal and being human. I finally suggest that Agamben's concept of 'bare life' and an eco-critical notion of stewardship concerning endangered species, as well as animals in general, both conceive of the animal as a new kind of immanent transcendence.

DANSK SUMMARY: Jeg tegner $i$ denne artikel et omrids af dyrenes betydning $i$ en religiøs kontekst (fra stammefolk til en kristen tradition) samt $i$ en filosofisk og økokritisk optik. Min tese er, at dyrene i mange kulturer har ansporet mennesket til at se dem som bindeled mellem livet i denne verden og en transcendent væren. I animistiske og totemistiske ontologier er dyrene txt forbundet med både mennesker og guder, hvorimod de $i$ de arkaiske religioner indgår $i$ et hierarki, hoor de, blandt andet gennem ofringer, udgør den medierende instans mellem mennesker og guder. Senere antager de hovedsagelig en metaforisk betydning som moralske sindbilleder. Vores egen tid oplever en stigende økologisk bevidsthed om dyrenes egen-værdi, og markante filosoffer som Derrida og Agamben har stillet spørgsmål ved den traditionelle grænse mellem dyr og mennesker, som antropocentrismen har levet højt på $i$ århundreder. Jeg hævder $i$ den 
forbindelse, at der hersker en indbyrdes forbindelse mellem Agambens begreb om det nøgne liv og en øko-kritisk omsorg for dyret, som gør det til en ny form for immanent transcendens.

KEYWORDS: Animals; immanent transcendence; symbolism vs. allegory; animism; analogism; philosophy; eco-criticism

\section{Indledning}

Ernst Cassirer har engang kaldt mennesket for et symboliserende dyr, animal symbolicum, og det må i den forbindelse tilføjes, at det er dyrene, altså de andre dyr, der fra tidligste tid har udgjort det primære symbol. De udgør et spejlvendt animal symbolicus, kunne man sige. Men hvad er der på spil i menneskets forhold til dyrene? Det er et spørgsmål med mange facetter, og det er nødvendigt at skaffe sig et fokus. I regi af dette tidsskrifts faglige profil ligger det lige for at tage et udgangspunkt i det religiøse forestillingsunivers. Også her åbner der sig imidlertid mange forskelligartede sammenhænge. Det samme gælder filosofihistorien, der i en kristen kontekst hænger ufravigeligt sammen med religionshistorien. Igen og igen dukker dyret op i forsøget på at bestemme det, der gør mennesket til netop menneske og ikke et dyr. Det er naturligvis umuligt at komme ind på denne kompleksitet i en enkelt artikel. Jeg vil derfor nøjes med at slå ned på nogle overordnede betydningsskift i forhold til den symbolske og begrebslige attraktionsværdi, der ligger i, at dyr både ligner og ikke ligner mennesker. Artiklen er først og fremmest ment som en selektiv oversigt, der samtidig afspejler min tese, nemlig at dyrs semantiske og ikonografiske betydning bedst forstås, hvis man tager udgangspunkt i den fænomenologiske optik, der forbinder dyrene med en immanent transcendens. Det er i denne dobbelt-natur, at dyret figurativt, narrativt og refleksivt fungerer som formidler mellem mennesket og menneskets Andet, hvad enten dette Andet er Gud eller en indre natur.

\section{Den fritgående brystfilet}

Vi mennesker forholder os hele tiden, direkte eller indirekte, til de livsvæsner, der omgiver os, og som vi med en i virkeligheden uhørt forenkling i dagligsproget omtaler som $d y r$. Dyr er jo alt lige fra edderkopper til orangutanger, selvom en orangutang, der øvrigt betyder 'skov-menneske' på malaysisk, alt andet lige er mere beslægtet med mennesket end med edderkoppen. Men hvorom alting er, omfatter disse 'dyr' ikke kun de biologiske arter, som homo sapiens jo selv hører hjemme blandt, men også denne arts selvspejlende projektioner. De er til stede overalt: som sproglige troper, som føde- og lædervarer, som kæledyr, husdyr, forsøgsdyr og zoologiske dyr. Og hvor forskellige disse 'dyr' end er, så er de alle spundet ind i relationer til mennesket. Mange af disse relationer er implicitte og ikke sjældent forbundet med fortrængning. Selvom en vegetarisk livsstil synes at vinde stadig større udbredelse i den vestlige verden, er menneskets indtagelse af kød immervæk så stort, at spiselige dyr masseproduceres i 
industrielle anlæg på utilbørligt minimale livsbetingelser. Og netop det enkelte individ bliver usynligt på vejen fra båsen til middagsbordet. Det bliver, som Carol J. Adams har formuleret det, 'an absent referent' (2010, 67), eller med religionshistorikeren Aaron Gross' udtryk 'an absent presence' $(2015,60)$. Det kommer på en pudsig måde til udtryk, når man i supermarkedets køledisk kan finde pakker med Fritgående Brystfilet fra De Danske Familiegårde. Med småt står der også Dansk kylling; men for alle os, der ikke selv slagter det dyr, vi spiser, er denne kylling usynlig i kødproduktet. Nok holder vi af vores kæledyr og fornøjes over de dyr, vi får øje på i naturen; men i det store hele er vores forhold til de livsvæsner, vi omgiver os med, præget af fortrængning. Alle de dyr, der omsættes til forbrug eller som må ofre deres liv i laboratorier for menneskeartens skyld, er lige så individuelle væsner som den undulat, kanin, hund eller kat, vi giver et navn og betragter som et familiemedlem. Men vi kan ikke rumme bevidstheden om dem, og vi behøver ikke at tænke alt for meget på dem, for vi ved jo, at dyr trods alt ikke er mennesker.

\section{Animisme, totemisme og analogisme.}

I andre samfund tænker man anderledes. Dyr er i virkeligheden ligesom mennesker, siger man blandt forskellige stammefolk, lige fra Achuar-folket i Amazonas regnskove til Bedamuni-folket på Papua Ny Guinea (Descola 2013, 4; 8-11; 24). ${ }^{1}$ Animistiske myter fortæller, at dyr og mennesker kan indgå ægteskaber med hinanden, at de har fælles forfædre, og blot i det ydre adskiller sig fra hinanden. Det er karakteristisk for de tribale religionsformers animistiske eller totemistiske forestillingsunivers, ${ }^{2}$ at menneskets forhold til dyrene er eksplicit og helligt. Og først og fremmest er det symbolsk. Selvfølgelig indgår man i forskellige konkrete relationer til dyrene, så symbolikken er på ingen måde løsrevet fra den direkte kontakt. Men det er i betydningstilskrivningen, at mennesker adskiller sig fra de dyr, de føler sig beslægtet med. Det interessante paradoks er, at man ved at understrege slægtskabet markerer forskelligheden, men at forskelligheden samtidig hviler på identifikationen. ${ }^{3}$

Vi genkender alle noget af os selv i dyrene og noget af dyrene i os selv. ${ }^{4}$ Også i handling deler vi aspekter med dyrene. Når en jæger nedlægger sit bytte, opfører han

1 Rane Willerslev $(2007,19)$ kan berette om den samme forestilling hos de sibiriske yukaghirer, som han har opholdt sig hos.

2 Jeg vil her henvise til Hans J. Lundager Jensens artikel i dette nummer af Religionsvidenskabeligt Tidsskrift m.h.t. Desoclas begreber om animisme, totemisme og analogisme, som jeg også i denne artikel støtter mig til.

3 Dette forhold går for så vidt igen i Genesis, hvor mennesket, Ish, først får sit navn, Adam, da han navngiver dyrene, Gen 1,20-21.

4 M.h.t. den måde, hvorpå mennesket ser sig i lyset af dyret, behøver man blot at tænke på de mange talemåder såsom 'at have en ræv bag øret', 'at være sulten som en ulv', 'frisk som en havørn', 'stærk som en okse', 'klog som en ugle', 'flittig som en bi', 'en sløv padde', 'et dumt svin', 'familiens sorte får', 'fræk som en slagterhund' , 'fattig som er kirkerotte', 'have en bjørn 
sig i princippet ud fra en jagt-strategi, der ligeså godt kunne være et rovdyrs; han lister sig ubemærket ind på sit bytte og sørger for at dræbe det hurtigt og effektivt. Men når jægeren tilhører et stammefolk i Amazon-junglen eller på de sibiriske sletter og forestiller sig, at dyret tilbyder sig selv som en gave, ${ }^{5}$ så ser han dyret gennem symbolets optik. Og her er der ikke tale om en anskueliggørende metaforik, som så ofte kendetegner dyrets fraværende nærvær i en moderne kultur, men om en udveksling af øjenkontakt, en intimitet i forholdet mellem liv og død (jf. Berry 2006, 6f.; Ingold 2011a, 13). Det er ikke fordi dyrenes og menneskenes liv i højere grad involverer hinanden hos stammefolk end i vores egen vestlige kultur, men for den indianske jæger, f.eks., er kontakten så direkte og konkret, at den angiveligt 'fanger og fortryller' tanken, for her at låne en formulering fra Cassirer $(1955,32){ }^{6}$ Eller som Ingold skriver: "At that crucial moment of eye-to-eye contact, the hunter felt the overwhelming presence of the animal" (2011a, 25). Jeg skal gerne indrømme, at jeg er lidt forbeholden over for såvel Cassirers som Ingolds påståede indsigt i, hvad andre skulle have tænkt og følt. Men myter og symboler blandt de pågældende stammefolk synes i det mindste at antyde en særlig 'forbindelse ' til dyret samt en ide om fælles sjælelighed.

Dyrene står også centralt i de arkaiske samfunds religiøse forestillingsunivers, men med betydningstilskrivninger, der generelt adskiller sig fra den animistiske og totemistiske omverdensforståelse. En af forskellene beror på overgangen fra en jæger-samler kultur til en agerbrugskultur med kvæghold. Gennem varetagelsen og udnyttelsen af domesticerede dyr udvikles et herredømmeforhold mellem mennesker og dyr, som også griber ind i den symbolske repræsentation. F.eks. var det almindeligt såvel i Indien (Benveniste 1969, 48) ${ }^{7}$ som i Romerriget (Richard Tapper 1988, 59) at sammenligne dyr med slaver, og i Mellemøsten sagde man, at vædderen vogtede over sin flok, som eunukkens vogtede over kejserens harem (jf. Ingold 2011a, 74). I et hittitisk ritual, som magisk tjente til at overføre en animalsk fertilitet til en mandlig 'patient', blev der rettet en bøn til sol-guden om, at han måtte fylde huset med sønner, døtre og efterkommere, på samme måde som tyren fyldte stalden med tyre (Ilan Peled 2019, 85).

Philippe Descolas begreb om en analogistisk fortolkningsramme synes her at være relevant (Descola 2013, 205ff.). ${ }^{8}$ Kort sagt kan man sige, at forholdet mellem guder, mennesker og dyr i en arkaisk kontekst defineres af et kosmologisk hierarki. Inden for en animistisk og totemistisk fortolkningsramme er de ontologiske forskelle mere flydende. I mange myter er dyrene ofte guder eller inkarnationer af guddommelige kræfter, og omvendt kan mennesker, specielt shamaner, forvandle sig til dyr. I kulten bærer

på', osv. I folkeeventyrene samt i fabeltraditionen fra Æsop til La Fontaine er det omvendt dyrene, der udstyres med menneskelige egenskaber.

5 M.h.t. til reciprociteten mellem den respekt, jægeren udviser over for dyret, og den villighed, hvormed det tilbyder sig som bytte eller skænkes af guden, se Colin Scott 1989, 204.

6 Cassirer taler generelt om den omverdensperception, der er karakteristisk for mytens symbolske former, men dyrene udgør, som sagt, et helt centralt element i disse.

7 Ifølge vediske tekster var det skik blandt hinduer at referere til husdyr som firbenede pasu og til slaver som tobenede pasu.

8 Se endvidere Lundager Jensen i nærværende nummer af Religionsvidenskabeligt Tidsskrift. 
ritualets deltagere dyremasker, der repræsenterer hellige ånder og særlige dyrearter, som stammen identificerer sig med og behandler med ærbødighed. ${ }^{9}$ Dyret inkarnerer med andre ord mere end det beslægtede livsvæsen, der umiddelbart træder mennesket i møde. Det manifesterer forbindelsen til en usynlig virkelighed af guder, sjæle og onde ånder (jf. Ingold 2011a, 93). ${ }^{10}$

Som hovedregel er guderne ikke længere dyr og dyrene ikke længere mennesker inden for en analogistisk orientering. Dog er dyrene stadig i mange henseender omgærdet af hellighed. I myterne ses de ofte som ledsagere til guderne eller som den skikkelse, en gud midlertidigt kan antage i menneskenes verden. Også i den praktiske og kultiske virkelighed repræsenterer dyrene aspekter af en guddommelig virkelighed, lige fra ikonografiske udsmykninger ${ }^{11}$ til alimentære koder og dyreofringer.

Mit grundlæggende spørgsmål er: Hvorfor lades dyrene med denne betydning? Og er der, når alt kommer til alt, noget i denne animalske symbolik, som også kommer til udtryk i vores egen moderne tankegang? Min tese er som sagt, at der er noget i menneskets opfattelse af og forhold til dyrene, der gør, at de i forskellige sammenhænge gøres til et symbolsk udtryk for en immanent transcendens. Det er mest oplagt i de ældste religiøse sammenhænge; men jeg vil også give nogle eksempler på, at forholdet kan læses frem i en moderne, filosofisk kontekst. Det kan påvises rent empirisk, at dyr i forskellige religiøse kulturer tillægges guddommelige eller - i en moderne forstand - overnaturlige egenskaber. Dog er det i lige så høj grad den symbolske repræsentation af dyret i fortællinger, udsmykninger, masker og figurer som de konkrete dyr, der rummer denne udtrykskraft. Spørgsmålet er, hvad det er, der gør, at dyr påkalder sig denne symbolske projektion? I hvilken forstand udtrykker de mere end det, øjet ser?

Dyrene omgiver os, og de forskellige arter deler mere eller mindre udtalte lighedstræk med vores egen art; men de konfronterer os også med en uudgrundelig alteritet. Når indianske myter fortæller, at dyr som jaguarer og hjorte lever ligesom mennesker i deres egne, afsondrede omgivelser, henvises der netop til en skjult virkelighed. Og når Vishnu vælger en bjørn som sin avatar, skyldes det, at han ikke direkte kan vise sig som gud i menneskenes verden.

Den forbindelse til det transcendente, som dyrets væsen tilskrives, har imidlertid ikke alene med de imaginære betydningstilskrivninger at gøre, men også med det forhold, at dyrene reelt befinder sig uden for vores sprogligt kommunikative verden, eller som det hedder hos Wittgenstein: "Selv hvis en løve kunne tale, ville vi ikke kunne

9 James Teit har således samlet en række myter, der beskriver Thompson-indianernes intime forhold til hjortene, jf. Boas 1917, $40 \mathrm{f}$.

10 Opfattelsen af, at en forfaders sjæl kan vende tilbage i et dyr, er særligt udbredt i Indus-dalens religioner, jainisme, hinduisme og buddhisme. Forestillingen findes også blandt indianske folk, f.eks. det sydamerikanske Waiwai-folk, jf. SFR, 191. M.h.t. dyrs relation til onde ånder, se f.eks. SFR, 53. På øen Mu Ngiki (Bellona), nord for Australien, hersker der en animistisk forestilling om at guder og forfædre kan vise sig gennem forskellige dyr, jf. Monberg 1966, $38 \mathrm{f}$.

11 Der kan henvises til Blankenburg (1975) med hensyn til udlægningen af dyresymbolikken ved lykkebringende amuletter og forskellige bygningsværkers apotropæiske stenfigurer. 
forstå den" (2009, 235: §327). Det er måske det mest dækkende udtryk for dyrets reelle transcendens. På den ene side spejler vi os i dyrenes egenskaber, hvilket fremgår af utallige sproglige og visuelle repræsentationer, på den anden side viser dyrene hen til noget fremmed. Vi ved trods alt ikke, hvad der går for sig i løvens sind.

Dyr spiller ofte en afgørende rolle i stammefolks skabelsesmyter, hvor de optræder som guddommelige væsner, ${ }^{12}$ og som sagt kan de i konkrete tilfælde inkarnere en forfader eller en guddom. Totemistiske samfund er kendetegnet ved, at forskellige dyrearter (undertiden også planter og genstande) udgør emblemer for forskellige klaner, der ser sig beslægtet med hver sin art. Klanen identificerer sig med bestemte egenskaber hos dette dyr, men som totem opfattes dyret samtidig som inkarnationen af en udødelig essens i det land, der er hjemsted for dem begge (Descola 2013, 146f.; Ingold 2011a, 114).

Elementer af totemisme kan genfindes i mange sammenhænge, der ikke har med klan-strukturens samfundsorganisering at gøre; ${ }^{13}$ men dyrenes emblematiske betydning synes alt andet lige at forsvinde, eller i det mindste at skifte karakter, med overgangen til pastorale samfund. Men også inden for den arkaisk-hierarkiske fortolkningsramme opfattes dyret som en bærer af transcendente egenskaber. Ét er, at guderne ofte tilskrives dyriske egenskaber, både mytisk og ikonografisk (som f.eks. i Ægypten), og i mange tilfælde viser sig i menneskenes verden gennem dyrets skikkelse: som f.eks. Zeus, der opsøger Leda i form af en svane og bortfører Europa i en tyrs skikkelse. Noget andet er, at dyr kan optræde som budbringere for guderne, eksempelvis ravnene Hugin og Munin, der meddeler Odin, hvad der går for sig i Midgård; de ørnelignede tordenfugle hos Ojibwa-stammen i Nordamerika, der bringer profetier til menneskene; makak-aberne, der i den japanske Shinto-religion fungerer som gudernes budbringere, eller ørne, der af middelalderens helgener blev betragtet som engle, når de bar bud fra Gud. Og således kunne man blive ved.

Dyrene kan stadig, inden for en værenshierarkisk tankegang, inkarnere guddommelige kræfter; men oftest sker det på et rent metaforisk niveau, som når den kristne mytologis Satan antager gedebukkens skikkelse (med rod i den græske skovgud Pan

12 F.eks. kalder de sibiriske tungusere hun- og han-bjørne for bedsteforældre og ærer dem for deres bidrag til verdens skabelse. Andamanerne refererer til firben og fugle, en chikade, en bille og en myre, som alle deltager i fastlæggelsen af dag og nat. Indianske myter fortæller ofte om prærieulven og andre dyr, der er med til at indrette verden og bestemme menneskenes lod.

13 F.eks. fortælles det om Skt. Cuthbert (634-687), at han holdt hånden over øen Lindisfarnes bestand af edderfugle, hvilket betød, at de ikke blot byggede deres reder i naturen, men også i huse og senge, på borde og ved altre. Ifølge Geoffrey af Coldingham skulle Roger af Embleton på et tidspunkt have bedt Skt. Bartholomæus om lov til at dræbe en af edderfuglene og tilberede den som føde. Hertil skulle den benediktinske munk have svaret: "You know not what you ask. Go rather to the neighbouring islands and take thence what you can. But do not presume to stretch forth your hand against those whom the lodging of this holy place has brought forth. They must enjoy the privilege of that great place”, jf. Alexander 2008, 158. 
og den romerske Faun), eller når pelikanen i Physiologos-traditionen ${ }^{14}$ ses som et billede på Kristus, fordi den hævdes at ofre sit eget blod for sine ungers liv. Der gives dog også eksempler på en middelalderlig dyresymbolik, som synes at overskride en rent allegorisk betydning.

Blandt de mange middelalderlegender, der fortæller om helgenernes forhold til dyrene, vil det være naturligt at fremhæve Frans af Assisi, der som bekendt prædikede for fuglene. I øvrigt fortæller Bonaventura i sin hagiografi om Frans, at han ofte frikøbte "lam, som blev ført til slagtning, fordi de mindede ham om det allersagtmodigste lam, som ville føres til slagtebænken for at løskøbe syndere" $(2002,82)$. Paulus omtaler netop Jesus som påskelammet, der lader sig slagte, for at rense og forny menneskene (1 Kor 5, 7-8), og det kunne derfor se ud, som om lammet primært har haft metaforisk betydning for Frans (Salter 2001, 42). Men hvis lammet alene har betydning som en påmindelse om Kristus, hvorfor skulle Frans så forbande de dyr, der dræber det, og forbyde mennesker at spise det?

Der er oplagte elementer af naturmystik hos Frans og hans brødre, og dyrene spiller en essentiel rolle som dyr i denne optik. Men når Frans taler til dyrene, henleder han først og fremmest deres opmærksomhed på Gud. Hvor det således i animismen er dyrene, der formidler kontakten til det guddommelige, er det i den middelalderlige analogisme helgenen, der formidler kontakten mellem Gud og dyrene. I den forbindelse er der tale om en naturalistisk fejlvurdering, hvis man alene vil forstå de dyr, Frans omgås og taler til, som rene sindbilleder. Deres betydning som hellige skabninger rækker dybere. På et tidspunkt fristes en af brødrene af en pung, der er tabt på vejen, men da han bøjer sig ned efter den, kryber en slange ud af den. "Broder", siger Frans da til sin rejsefælle, "penge er for Guds tjenere ikke andet end en djævel og en giftig slange" (Bonaventura 2002, 72). Nok kunne det her se ud til, at slangen blot konnoterer den onde selv; men da den traditionelt repræsenter Satan i en kristen-mytisk kontekst, tyder det ikke desto mindre på, at den også som slange inkarnerer en dæmonisk natur. I Genesis, hvor den leder Eva i fristelse, kender den endog Guds vilje.

Man kan skematisk illustrere forskellen på forholdet mellem guder, dyr og mennesker i henholdsvis en animistisk-totemistisk og en analogistisk symbolik med følgende figurer:

14 Physiologos er et værk fra antikken, hvis oprindelige forfatter er ukendt, selvom mange i tidens løb er blevet tilkendt æren (heriblandt Aristoteles, Johannes Chrysostomos, Athanasius, Ambrosius og Hieronymus). Værket omhandler en broget og ofte fantasmatisk fauna, der hovedsagelig fungerer som allegori for en kristen morallære. 


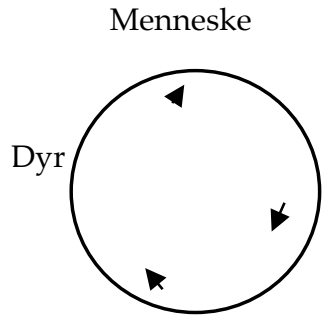

Gud/guder/forfædre

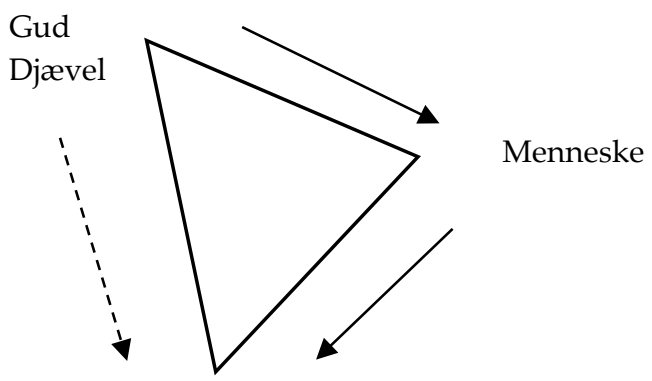

Dyr

Overgangen mellem mennesker og dyr og mellem dyr og guder er flydende i en animistisk-totemistisk orientering. Shamanen kan således forvandle sig til et dyr, og et dyr kan, som nævnt, optræde på gudens vegne eller som direkte inkarnationer af guder og forfædre. Guder og mennesker kan kun sjældent forvandle sig til hinanden på samme måde. Dyret udgør altså det nødvendige mellemled, og det er netop et af de konstituerende træk ved dets betydning som immanent transcendens. I det vediske heste-offer var det f.eks. skik, at offerpræsten tog fat om hestens hale, så den kunne tage ham med til himlens rige. Det er øjensynligt dyret snarere end mennesket, der kender vejen.

Mennesker har ikke altid i alle kulturer skelnet begrebsligt mellem sig selv og dyrene; men til gengæld har man til enhver tid tilskrevet andre livsvæsner betydninger, som både peger ind i menneskenes egen verden og ind en fremmed realitet. For at give et moderne eksempel, beretter teologen og filosoffen Martin Buber om en barndomsoplevelse, hvor han strøg sin hest over manen. 'Jeg må tilstå, at det, jeg oplevede i berøring med dyret,' skriver han, 'var det Andet, det Andets uhyre andethed' (2002, 32 min oversættelse). I øvrigt er det primært i filosofien, at dyret i dag optræder som bærer af denne alteritet. Og selvom der historisk (og geografisk) er lang vej fra tribale myter og arkaiske tankesystemer til samtidens filosofiske og øko-kritiske debatter, er der også interessante forbindelseslinjer. Jeg skal senere forsøge at trække nogle af disse frem i lyset, men først gælder det nogle nedslag i den mellemliggende historie.

\section{Dyret som metafor eller symbol}

Når det gælder en religionsfænomenologisk forståelse af dyrenes betydning, er der grund til at skelne mellem metaforik og symbolik. Hvor metaforik betegner en overførsel af en eller flere definerbare betydninger fra ét genstandsfelt til et andet, forstår jeg symbolik som en repræsentation af konnotationer uden fast definerbare grænser. Et symbol rummer således en større betydningsekstension end metaforen. 
Distinktionen mellem metaforik og symbolik i forbindelse med animismen rejser et spørgsmål til, hvordan det skal forstås, når antropologerne Philippe Descola (2013, 4-11) og Eduardo Viveiros de Castro $(2015,229)$ påpeger, at stammefolk typisk betragter dyr som forklædte mennesker. Indianske myter fortæller f.eks., at dyrene tager deres skin eller pels af, når de er hjemme hos sig selv, hvor de lever på samme måde som mennesker. Men hvad vil det - ud over de praktiske gøremål (som at vaske tøj og tilberede mad) - sige at være menneske i den forbindelse? Det pointeres, at dyr (ofte) opfattes som personer; men det stiller blot endnu et spørgsmål til, hvad det indebærer at være en person. Den amerikanske antropolog Alfred Irving Hallowell, der bedrev feltstudier blandt Ojibwa-indianerne, beskrev, hvorledes de så dyr som personer i den forstand, at de ligesom mennesker havde følesans, vilje, hukommelse og evnen til at kommunikere $(1960,42)$. Netop kommunikationen mellem dyr og mennesker, eller, som Tim Ingold understreger, den indbyrdes sociale kontakt, er det, der udgør det primære kriterium for at tale om dyr som personer (2015). Og som Aaron Gross tilføjer: “To speak of mutual social interactions - and mutual religious interactions - between humans and animals will continue to appear absurd so long as animal personhood is as metaphorical in a way that human personhood is not" $(2015,111)$.

Med henvisning til det melanesiske begreb kamo, der både kan oversættes med 'life' og 'personage', pointerer Descola, at et animistisk person-begreb ikke nødvendigvis er forbundet med a "clearly defined shape nor any essential nature" $(2013,25)$. På den anden side finder han også animismen kendetegnet ved forestillingen om en universel substans (ibid., 130) eller en spirituel essens (ibid., 131), der er fælles for planter, dyr og mennesker, og han forstår vel at mærke denne essens som "humanity as a condition" (ibid., 11; ligeledes Viveiros de Castro 2015, 229). Men hvordan hænger disse prædikationer indbyrdes sammen? Selv hælder jeg mere til Rane Willerslevs formulering, nemlig at "nonhumans possess qualities paralleling those of human selves or persons" (2007, 19, min understregning). I så fald er der ikke tale om en metaforisk overførsel af betydning fra mennesker til dyr, men om oplevelsen af et frllesskab mellem alle livsvæsner, en med-væren, der får sit symbolske udtryk såvel i tanke som i praksis (myter, offerhandlinger, dyredanse). Det stemmer også overens med Viveiros de Castros perspektivistiske udlægning af animismen som en forestilling om, at dyr ser den menneskelige verden på samme måde, som menneskene ser dyrenes verden. For jaguaren er dyre- og menneskeblod således "manoic beer" (2004, 6; 2015, 55ff.). I tråd med en lignende perspektivisme refererer Tim Ingold til Ojibwa-indianernes fortælling om, at en mand, der giftede sig med en kvindelig tordenfugl, fik serveret slanger og tudser, hvilket imidlertid blandt tordenfugle-familien gik for at være en 'bæver' (Ingold, 2011a, 92).

Min pointe er, at vi danner os det bedste indtryk af en animistisk forestillingsverden, hvis vi er opmærksomme på en overførsel af betydning, der går begge veje: fra dyrenes til menneskenes verden og fra menneskenes til dyrenes. Et sådant betydningsfelt er imidlertid snarere symbolsk end metaforisk, eftersom der ikke gives et fast grundlag, hvorfra den overførte betydning hentes. Tværtimod skifter grundlaget ka- 
suistisk i overensstemmelse med det relevante fortolkningsaspekt. I dette åbne betydningsfelt melder også den guddommelige reference sig. Dyrene lever ikke kun, som om de er mennesker, men også som om de er guder (se f.eks. Boas 1917; SFR, 33; 58 ff; $86 \mathrm{f}) .15$

Dyr opfattes med andre ord som forfædre, som brødre og søstre, som beslægtede væsner, ikke fordi de som sådan er forklædte mennesker, men fordi dyr og mennesker grundlæggende ejer samme sjæl. Begrebet for et sådant sjælefællesskab kan ikke i animismen skelnes fra det simpelthen at være et levende væsen, og netop begrebet om et sådant livsvæsen synes at være en fællesnævner for gloser som det melanesiske kamo, det hebraiske næfæsh hajah og det græske zōon. Jeg hævder på ingen måde, at ordene uden videre kan oversættes til hinanden. Min pointe er blot, at den animistiske forestilling om en person snarere knytter sig til dette livsprincip end til artspecifikke egenskaber og en ydre fremtrædelsesform.

\section{Dyreoffer og mysteriekult}

I offerkulten, der kronologisk strækker sig fra en tribal kontekst til mere komplekse bysamfund, bærer offerdyret typisk sin guddommelige betydning med sig, selvom den egalitære besjælethed, der kendetegner animismen, erstattes af en hierarkisk orden, hvor dyret er et middel snarere end en partner. Dog indgår dyr og guder stadig i tæt forbindelse med hinanden. Det er i den forbindelse værd at citere William Robertson Smith:

All the great deities of the northern Semites had their sacred animals, and were themselves worshipped in animal form, or in association with animal symbols, down to a late date; and that this association implied a veritable unity of kind between animals and gods is placed beyond doubt, on the one hand, by the fact that the sacred animals, e.g. the doves and fish of Atargatis, were reverenced with divine honours; and, on the other hand, by theogonic myths, such as that which makes the dove-goddess be born from an egg, and transformation myths, such as the of Bambyce, where it was believed that the fish-goddess and her son had actually been transformed into fish (Robertson Smith 1972, 288).

Den kontekst, der mere end nogen anden, aktiverer dette betydningskompleks, er offerkulten, og her trækker traditionen ifølge Robertson Smith på en totemistisk forhistorie:

[T] he conjecture that sacrificial animals were originally treated as kinsmen, is simply equivalent to the conjecture that sacrifices were drawn from animals of a holy kind, whose lives were ordinarily protected by religious scruples and sanctions; and in support of this position a great mass of evidence can be adduced, not merely for Semitic sacrifice,

15 Vi finder et interessant eksempel hos sydamerikanske Waiwai-folk, hvor en shaman i sin fortælling om danse-festens indstiftelse refererer til hovedaktørerne som forskellige dyrefolk i urtiden, der "hverken var rigtige mennesker eller rigtige dyr, men dyrefolk", SFR, 194 (= Podemann Sørensen 1988). For mig at se svarer denne semi-transcendente kategori til mit begreb om immanent transcendens. 
but for ancient sacrifice generally (289).

Tilsvarende er der også eksempler på levn af den animistiske respekt for dyret, når bystatens athenæere ifølge Porfyrs referat (De abst. 2.30 = Porphyry 2017, 80) var forpligtet til at restaurere offerdyret ud fra dets knogler og skin. ${ }^{16}$ Dyrenes symbolske betydning forsvinder med andre ord ikke uden videre med overgangen til en hierarkisk opdeling af forskellige værensformer. Alligevel synes der at være en tendens til, at den animistiske betydningsekstension svinder ind med tiden, eller med andre ord, at der sker en forskydning fra symbolik til metaforik og allegori. Dyrenes fremtrædende og hellige betydning i den old-ægyptiske civilisation udgør en nævneværdig undtagelse. Her er der ikke blot tale om zookefale guder (dvs. guder med dyrehoveder), hvis betydning ikke uden videre kan reduceres til de pågældende dyrearters egenskaber; men ægypterne omfattede også konkrete dyr med så stor ærbødighed, at de blev begravet efter samme rituelle forskrifter som mennesker. Herodot (Historier 2.65) fortæller, at der var dødsstraf for at slå disse dyr ihjel.

Imidlertid finder der i middelhavskulturerne - i den periode der kaldes for aksetiden - et generelt skifte sted fra en oplevelse af fællesskabet mellem alt liv til menneskets optagethed af sin egen individuelle skæbne. Det gælder i parentes bemærket også den ægyptiske kontekst, hvor det dog ikke, som i de omkringliggende kulturer, førte til en begyndende afvikling af dyrenes egen guddommelighed. Det synes til gengæld at være tilfældet i den græske nabokultur. For nok fortæller de græske myter, at guder som Zeus og Dionysos kunne optræde som tyr, slange og gedekid; men det gjaldt ikke omvendt, at de konkrete dyr inkarnerede de pågældende guder.

Men som sagt begyndte mennesket at fjerne sig fra fællesskabet med dyrene ved bl.a. at udvise en særskilt bekymring for sin egen skæbne. Mysteriereligiøse indvielseskulter, der fokuserede på individets status i efterlivet, vandt bl.a. stor udbredelse i Grækenland. Også her spillede dyreofferet en central rolle, bl.a. i den forstand, at den kommende initiand som forberedelse til det aporetiske (uudsigelige) mysterieritual i Eleusis skulle ofre en gris på vegne af sig selv. Grisen, som initianderne var forpligtede til at anskaffe sig for egne midler, og som de skulle bade i floden, ligesom de skulle bade og rense sig selv, måtte de efterfølgende ofre til de eleusinske gudinder, Demeter og Kore. Grisen repræsenterede initiandens tilhørsforhold til gudinderne; men det er svært at sige præcist, hvad den egentlig stod for. Idet dens liv blev skænket til gudinderne, modtog initiandene deres gunst og kunne se frem til en bedre skæbne efter døden (Homers hymne til Demeter 480-2).

Til trods for den gensidige participation mellem dyr og menneske er grisen dog samtidig et ydre bindeled mellem menneske og gud i den forstand, at grisen slagtes, mens initiandens eget legeme forbliver ubeskadiget. Sammenligner man med initiander blandt Sepik-folket på Papua Ny Guinea, må de derimod gennemgå en smertefuld tilskæring af deres overkrop. Sårene vil så danne ar, der, idet de ligner krokodilleskæl, manifesterer det indre slægtskab mellem mennesker og krokodiller. I stedet for dette

16 M.h.t. en lignende praksis hos stammefolk, se Hitoshi Watanabe, 1994, 59 ff.; specifikt hos Samerne, SFR 47. 
slægtskabsmotiv optræder grisen i den oldgræske kontekst som en sakral substitution; grisen træder i stedet for initianden. Analogt fortælles det i Demeter-hymnen, at grise suges ned i underverdenen sammen med Kore, da hun bortføres af Hades. Dyrene inddrages således i den guddommelige sfære, hvilket også kommer til udtryk i kvindekulten Thesmoforia, hvor de kastes levende ned i underjordiske kamre til ære for Demeter (Burkert 1983, 259). Man kan ikke sige, at de som sådan inkarnerer det guddommelige. Modsat bjørneungen, der kvæles til døde i den animistisk orienterede ainukult i Japan, ofres grisen ikke som et guddommeligt væsen $i$ sig selv, men på vegne af mennesket. Dette er et betydningsfuldt skift. Det er menneskets individuelle skæbne, det i aksetiden kommer an på. Generaliserende kan man sige, at det i regi af de arkaiske samfund er mennesket, der via dyret som et ydre bindeled søger kontakt til guderne, mens det i stammesamfundet var forfædre, ånder og guder, der satte sig i forbindelse med menneskene gennem dyrene, eller shamanen, der i dyrets form opsøgte det hellige.

Dog findes der også rester af denne forestillingstype i Grækenland, om end den i Pythagoras' tilfælde kommer til udtryk inden for en soteriologisk diskurs. Xenofanes fortæller nemlig, at Pythagoras en dag gik i rette med en mand, der pryglede en hund, for i hundens hyl havde filosoffen genkendt sjælen af en afdød ven (Diogenes Laertius, Vita 8.36). Anekdoten er muligvis ment som en vittighed; men det ændrer ikke på, at der i Grækenland herskede forestillinger om reinkarnation (metempsykhosis), hvor mennesker blev genfødt som dyr, mennesker eller guder. Men selvom Pythagoras efter sigende skulle have sagt, at alt, der er født med liv, skal betragtes som beslægtet (pánta ta ginómena émpsykha homogenē dei nomítsein), er der ikke desto mindre tale om et værenshierarki, hvor menneskets sjæl i kraft af det valg, den tager efter døden, enten genfødes som et dyr eller helt frigør sig fra fødslernes cyklus (hvilket er det samme som sjælens tilbagevenden til dens guddommelige ophav).

Som et eksempel kan nævnes Platons gengivelse af Pamfylieren Ers vision om, hvad sjælene gennemgår i det hinsides på overgangen til en ny inkarnation (Platon, Staten 10, 618a). Sjælene skal således selv vælge deres egen lod, og en profet lægger i den forbindelse forskellige livsformer frem foran an dem. Blandt disse er der alle slags dyre- og menneskeliv, såvel tyranners som dydige personers (618a-b). Det ord, der bruges om dyrene, zōon, kommer af ordet for liv, zōe. Dyrene omtales altså blot som livsvæsner. Det, der adskiller de forskellige arter fra hinanden, er bios, den konkrete livsform, og det samme ord anvender Platon om det enkelte menneskelivs moralske karakter. Der optræder således en rent sproglig analogi mellem de livsformer, der giver sig udslag i forskellige dyrearter på den ene side, og de livsformer, der viser sig gennem en etisk eller uetisk livsførelse 'for menneskets vedkommende' (anthrōpinos). Der er tydeligvis tale om en lighed med, om ikke ligefrem inspiration fra, den indiske karma-lære (jf. McEvilley 2002, 98f). Pointen i nærværende forbindelse er imidlertid blot, at der på den ene side stadig - i det mindste i Platons mytologisk-pædagogiske univers - tænkes i glidende overgange mellem dyrets og menneskets sjæl, og på den anden side at de enkelte dyrearters kendetegn udgør en underforstået parallel til menneskelige egenskaber. Denne kobling synes på den ene side at have sin historiske 
klangbund i totemismen, men peger på den anden side også ind i en tankegang, hvor dyriske egenskaber tillægges en mere metaforisk betydning. Den udvikling skulle i løbet af senantikken og middelalderen vise sig at blive mere og mere udbredt.

Når Lucius Apuleius (124-170 e.Kr.) således beretter om sin egen forvandling til et æsel, hvilket ganske vist sker ved trolddomskraft, tjener det som illustration af foragtelige og latterlige egenskaber. Han må således, som en allegorisk forberedelse til indvielsen i Isis-mysterierne, forskellige genvordigheder igennem, før han under Isis' vejledning genvinder sin menneskelige skikkelse og til sidst initieres til en højere, guddomslignende status. Apuleius' transformation er tydeligvis tænkt ind i et værenshierarki, der fører fra den laveste, dyriske bios ${ }^{17}$ til den bios, der, som det hedder hos Platon, "ligner gudens så meget som muligt" (Theaitetos, 176a-177a). Bortset fra at Apuleius' fortælling ejer fællesskab med eventyrenes forvandlingstema, der også var udbredt i oldtidens folklore, eksemplificerer den også en allegorisk (og ironisk) anvendelse af dyrets bios, der demonstrerer afstanden til den animistiske tankegang. For nok bliver Apuleius til et æsel med alle de begrænsninger, herunder tabet af evnen til at tale, der hører æslets værensform til, og nok kommunikerer han i denne ekstraordinære grænsetilstand med gudinden selv. Det drejer sig dog først og fremmest om Apuleius', som først da han vender tilbage til sin menneskelige skikkelse, fuldbyrder sin egen skæbne gennem indvielsen til Isis. Æsslet tjener til syvende og sidst kun som illustration af den ydmygende grænsetilstand, han må igennem, før han kan træde over tærsklen til evige guders rige (1950, 241).

\section{Kristne dyr}

Som sagt antager dyrene i stigende grad en metaforisk betydning, hvilket imidlertid tilslører, hvad det er ved dyrene, der inspirerer menneskets sanseoverskridende forestillingsevne. Når Thomas Hobbes f.eks. siger, at mennesker er som ulve over for hinanden (homo homini lupus), er det en allegorisk stereotypi vedrørende ulven, der har betydning for hans pointe, ikke ulve som sådan. Når romerne imidlertid støbte en bronzefigur af den ulv, deri følge sagnet ammede byens grundlæggere, Romulus og Remus, kan man ikke sige, at dyret blot havde en illustrativ betydning. Dyrets væsen, som det opleves af mennesker, rummer således både elementer, det er oplagt at udnytte metaforisk, og elementer, der rummer et dybere værensfællesskab. Tidligere kom det sidste særligt til udtryk i en religiøs kontekst; i dag skal man søge i litteratur og filosofi for at finde det. Men jeg vil generelt gå så vidt som til at mene, at der selv bag den metaforiske overflade gemmer sig en anden betydningskilde, hvor det forhold at mennesker ofte tillægges dyriske egenskaber, ikke lader sig adskille fra det forhold, at dyret også tillægges menneskelige egenskaber. Den dobbelte betydningsoverførsel er heterotopisk i den forstand, at mennesket samtidig ser sig selv som noget andet, når

17 Som Robert Graves skriver: "In Apuleius' day the ass typified lust, cruelty and wickedness", jf. Apuleius 1950, 10. 
det spejler sig i dyret. ${ }^{18}$ Det er denne alteritet, vil jeg hævde, der er hemmeligheden bag dyrets symbolske tiltrækningskraft. Når Irenæus forbinder evangelisterne Matthæus, Markus, Lukas og Johannes med henholdsvis mennesket, løven, oksen og ørnen (på baggrund af Åb 4,7), zookefalt fremstillet ved døbefontene i Aarhus og Haderslev, er den metaforiske begrundelse kun overfladisk relevant. De ikonografiske fremstillinger udtrykker et overskud af mening. Uanset om det kun er dyrenes hoveder eller hele kroppe, der afbildes, så er det ikke kun metaforen, der ses, men slet og ret mennesket, løven, oksen, ørnen, der alle - for at understrege deres hellighed - er bevingede. Samtidig angives det hellige gennem dyrets andethed - en alteritet, der også smitter af på Matthæus som et bevinget menneske. Menneskeskikkelsen er ikke længere blot en menneskeskikkelse, men et væsen, der optræder på lige fod med - og med samme ophøjede betydning som - dyrene. I relation til evangelisterne viser dyrene sig altså endnu som symboler, og som symboler efterlader de en betydning, der rækker ud over metaforen.

Min påstand er, at der selv i de metaforiske dyrerepræsentationer gemmer sig et mere eller mindre implicit betydningslag, der har rod i en magisk-religiøs erfaringsverden. Et oplagt eksempel på den magiske dimension er de mange dyrefigurer, der med et angiveligt apotropæisk formål udsmykker gavle og gesimser verden over (jf. Blankenburg 1975). Jeg tænker, at det netop er i den ikonografiske repræsentation af dyret, at den intuitive opfattelse af dets 'numinøse' væsen virker stærkest, mens dets verbale repræsentation i fabler, sagn og eventyr trækker over imod en metaforisk entydighed. Forskellen træder i hvert fald markant frem, hvis man - om end rent anakronistisk - sammenligner de palæolitiske hulemalerier med de moraliserende fabler hos Æsop. Men det er i denne udstrækning mellem de visuelle udtryk, der fastholder og ophøjer menneskets indtryk af dyrene, og den narrative transformation af deres væsen til menneskelignede egenskaber, at omfanget af deres noetiske og æstetisk-symbolske betydning for mennesker skal ses.

I middelalderen finder vi en udbredt tendens til moraliserende beskrivelser af dyrenes livsform - skiftevis som udtryk for et fromt og et syndigt levned. Samtidig prydes bøger, malerier, våbenskjolde, sø- og landkort af ekspressive illustrationer omfattende alt fra kendte dyrearter til groteske monstre. Her træder æstetikken klart i stedet for en moralsk kodificering. Den betydning af immanent transcendens, der bestandigt ligger som et mere eller mindre forløst potentiale i menneskets perception af dyrene, gør sig gældende i denne spænding mellem den verbale udlægning og det nonverbale indtryk. Antagelig ligger det implicitte betydningsoverskud også til grund for den tvetydighed, hvormed karakteren af den enkelte dyreart bestemmes. ${ }^{19}$ Således optræder

18 Min brug af begrebet heterotopi er inspireret af Foucault 1984, 4.

19 "The creatures are twofold", som der står at læse i Physiologos, "the praiseworthy and the blameworthy" $(1979,8)$, men også inden for en enkelt art kan dyrene eksemplificere såvel det gode som det onde (f.eks. bæveren, 52 [xxxvii]). På den ene side forekommer dyr, der som løven, pelikanen og ørnen tager sig kærligt af deres afkom, ligesom Gud tager sig af de troende (3 [i]; 9 [vi], 12 [viii]); på den anden side forekommer der urene dyr, der som ibisen lever 
løven i en litterær tradition fra Physiologos over middelalderens bestiarier til C.S. Lewis' The Chronicles of Narnia som et billede på Kristus. Ofte fremstilles løven som et venligsindet dyr, som munke og andre hellige personer formår at tæmme. Dog var det heller ikke ualmindeligt for anakoreterne, de ægyptiske 'ørkenfædre', at forbinde løven med djævelen selv (jf. Alexander 2008, 25; E.P. Evans 1896, 88). I Johannes' Åbenbaring smelter løven endvidere sammen med en bjørn og en panter til et monster, der “åbnede munden til bespottelser mod Gud, det spottede hans navn og hans bolig og dem, der har bolig i himlen" (Åb 13,6).

Implicit i det betydningspotentiale, der tilskrives dyrene, råder således en ambiguitet, der gør, at de aldrig fuldstændigt beherskes semantisk. Den indre spænding mellem det sammenlignelige og det fremmedartede ved dyret kommer også til udtryk i den aparte blanding af moralske formaninger og zoologiske 'oplysninger', som er karakteristik for middelalderens bestiarier. På den ene side danner dyrenes liv moralske eksempler, der illustrerer en kristen livsførelse; på den anden side repræsenterer de også, for de vilde dyrs vedkommende, en omgivende natur, som mennesket fors $\varnothing-$ ger at beherske gennem klassifikation og navngivning. Forskellen mellem vilde og domesticerede dyr udgør i virkeligheden ikke den store forskel, for alle dyr danner både en omverden til mennesket i geografisk og psykologisk forstand. Det bemærkelsesværdige i en middelalderdiskurs er, at den eksotiske del af denne omverden først og fremmest rummer dyr fra en litterær overlevering. Den omfatter såvel fabelvæsner (griffen, sphinxen, basilisken, enhjørningen, satyren og sirenerne) som en lang række vilde dyr, der ikke kendes ved selvsyn, men fra andre værker, der traditionelt placerer dem i Indien og Ætiopien (hvilket i øvrigt udgør prototyper på eksotiske lande, snarere end de faktiske lokationer).

Lad mig give et eksempel, hvor et fromhedsaspekt, en zoologisk interesse og en æstetisk merværdi glider sammen. Det drejer sig om Lucas Cranach den ældres portræt fra 1526 af Kardinal Albrecht von Hohenzollern-Brandenburg, der afbildes som kirkefaderen Hieronymus i sit arbejdsværelse (jf. Friedmann 1980, fig. 104). I billedets forgrund ses den tamme løve, som Hieronymus ifølge legenden befriede for en torn i poten. Løven omgives desuden af en undulat, agerhøns, fasaner med et kuld unger, en bæver, en hjort, et egern og en hare; dyr, der alle de hentet ind fra det traditionelle bestiarie-galleri. Billedets hovedmotiv er vel den hellige myndighed, hvormed Hieronymus på lige fod med samtidens helgener har tæmmet et vildt dyr, endda en løve med dens konnotationer af kraft og dominans i naturen. Men billedets æstetiske organisering afslører også et andet betydningslag. Arbejdsværelset, der repræsenterer det

af ådsler (25 [xvii]), eller hvalen Aspideceleon (45 [xxxi]), agerhønen (46 [xxxii]), den bedrageriske ræv (27 [xviii], havdybets drage (42 [xxx]) og fabelvæsnerne (23 [xv]), der alle repræsenterer djævelen. Den ambivalente udlægning af dyrets indre kvaliteter viser sig også i den forsatte bestiarie-tradition som eksempelvis Bodley 764-manuskriptet, hvor gedebukken på den ene side fordømmes for dens liderlighed (Richard Barber 1992, 83), mens geden andre steder lovprises for dens klarsyn (den alvidende Gud) og lyst til som Kristus at opholde sig i bjergene (de kristne kirker) (54). At fastholde et entydigt moralsk perspektiv var, som Barber skriver: "a problem for the compiler of the bestiary, because the same creature might well represent both good and evil" (8). 
civiliserede livs intellektuelle centrum, invaderes af dyr fra den vilde natur. Nok fokuserer maleriet på kardinalen; men det udgør samtidig et zoologisk udstillingsvindue. Dyrenes markante tilstedeværelse i billedets forgrund udelukker, at de alene tjener som ornamentering.

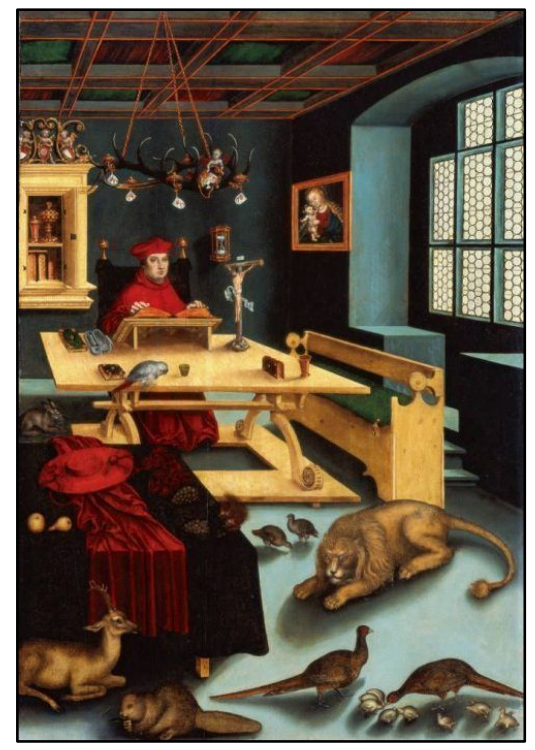

Lucas Cranach, Albrecht von Brandenburg som Hieronymus (1526)

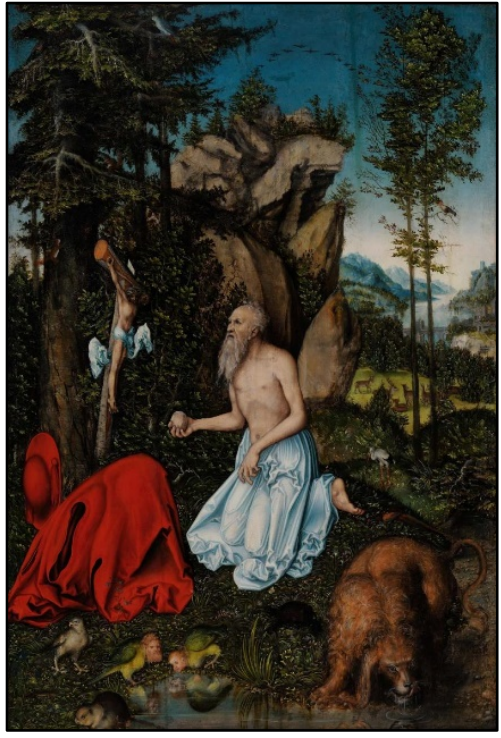

Lucas Cranach, Hieronymus som eneboer (1525)

I et af Cranachs andre malerier fra samme periode ses Hieronymus under sit bodsophold i den vilde natur. Her holder han blikket ufravendt fæstnet på et ikon af den korsfæstede og ænser tydeligvis ikke de dyr, der omgiver ham. Men det bemærkelsesværdige er, at dyrene i billedets forgrund - en bæver, en falk, den trofaste løve, samt to harpyer, der drikker af en skovsø - har blikket vendt ud mod tilskueren. Dyrene på Cranachs malerier fremstår ikke kun som underordnede væsner i Guds skaberværk, men også som æstetisk interessante væsner i egen ret. ${ }^{20}$ Måske vidner de også om den naturhistoriske interesse, der voksede frem i tiden og efterhånden skulle erstatte bestiariernes moralske fabler med fagkyndige opslagsværker. Hvorom alting er, udtrykker dyrene en implicit andethed i forhold til billedernes angivelige fremstilling af Hieronymus' fromhed. Det hemmelighedsfulde blik, de møder tilskueren med, fortæller, at de ikke lader sig reducere til en metaforisk og allegorisk betydning. De udgør i stedet en slags flydende betegnere, hvor overgangen fra hellighed til naturlighed uhindret kan finde sted.

20 Det samme må siges om hans maleri af Paradiset (1530), hvor det klart er dyrene, der dominerer billedet, igen i forgrunden. Endvidere kunne man henvise til Hieronymus Bosch's triptykon (1490-1510) Lysternes have, der ligeledes vrimler med dyr, heriblandt fugle i monstrøst overnaturlig størrelse. 


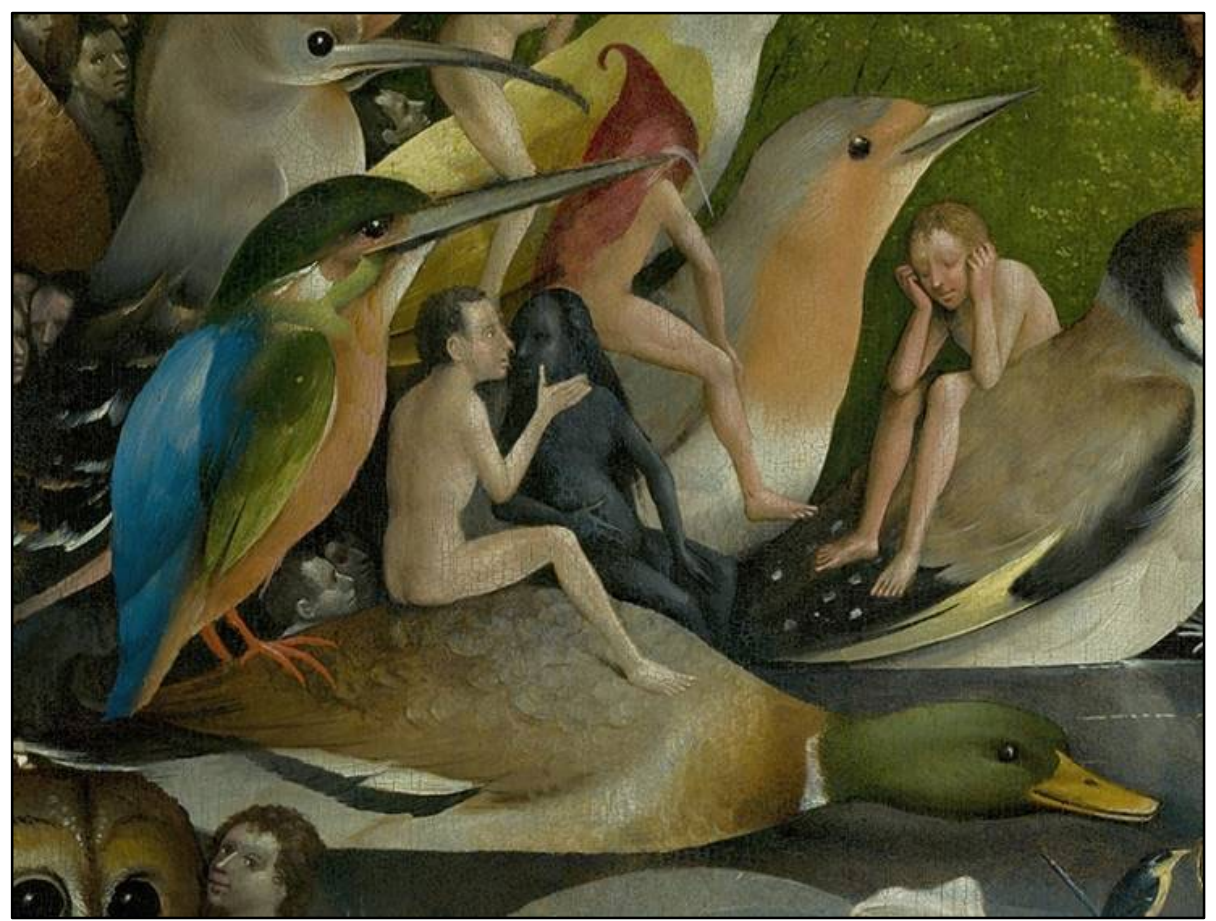

Hieronymus Bosch, udsnit fra Lysternes Have (1490-1510)

Men dyrene havde ikke kun betydning som moralske og æstetiske motiver. Også de konkrete dyr blev tillagt hensigter, som blandede sig med en menneskelig selvforståelse. Dette kommer på en særlig og for et moderne sindelag grotesk måde til udtryk i de middelalderlige dyreretssager. Vidt forskellige dyr fra sværme af insekter til aggressive grise blev taget alvorligt som moralske subjekter. I den forbindelse tog den kirkelige ret sig typisk af skadedyr (f.eks. insekter og rotter), mens den verdslige domstol bragte individuelle husdyr for retten. I 1386 i den franske by Falaise blev en so, der var dømt til døden for at have dræbt en dreng, ført frem på Rådhus-torvet i mandetøj og eksekveret til offentligt skue (Evans 1906, 140). En anden so blev i 1457 i Savigny dømt til hængning fra bagbenene, fordi den var fundet skyldig $i$ at have dræbt en 5-årig dreng. Dens pattegrise blev ligeledes anklaget, fordi de ved anholdelsen havde blodstænk på sig. Dog blev de frifundet, da der ikke kunne føres bevis for, at de aktivt havde deltaget i ugerningen. Også rotter, der i Autun havde forgrebet sig på byens afgrøder af byg, blev anklaget og tilsagt fremmøde i retten; men advokaten Bartholemew Chassennée forsvarede dem med, at de af angst for katte, der lå på lur efter dem, ikke kunne forventes at indfinde sig ved domstolen. Han endte med at få dem frikendt (jf. Evans 1906, 18-20).

Hvor aparte disse beretninger end forekommer i dag, så udtrykker de den konsekvente forestilling om en kristen verden, der gennemtrænges af en moralsk orden. Men selvom dyr og mennesker tillægges samme, eller i det mindste sammenlignelige, 
egenskaber og motiver, har den grundlæggende tankegang næppe meget med animisme at gøre. Dyrene er først og fremmest blevet til pladsholdere for en overspændt moralitet, der har brug for at omtolke blinde naturkræfter. I den forstand modsvares deres alteritet i forhold til mennesket samtidig af en alteritet i forhold til naturen. Man kan derfor betragte dyreretssagerne som en rituel håndtering af det onde; alt, der bryder med en gudsskabt orden, er udtryk for djævelens virke, uanset om han giver sig til kende i et dyr eller et menneske.

Men når nu dyrene har spillet så vigtig en rolle i middelalderen (som bindeled mellem natur og kultur, det gode og det onde, menneske og gud), kan man undre sig over, hvorfor man ikke videreførte den antikke offerkult, hvor dyrene jo også blev tildelt en formidlende funktion i forholdet mellem mennesker og guder? Der er formentlig mange grunde til, at offerkulten efterhånden blev indstillet; men idéhistorisk kan man henvise til, at Jesus erstattede dyreofret. ${ }^{21}$ Han var så at sige det sidste dyr, påskelammet, der ofrede sig selv på menneskenes vegne (1 Kor 5,7; Rom 3, 24-25). ${ }^{22}$ Det var ikke længere dyret, men den inkarnerede Gud selv, der optrådte som bindeled mellem det menneskelige og det guddommelige. Det ydre hierarki (mellem dyr, mennesker og Gud) blev erstattet af et indre. Mennesket måtte ofre noget af sig selv, af sin egen natur, med henblik på frelsen, ikke det konkrete dyr, som man kunne købe sig til. Således fandt der en ejendommelig association sted mellem det dyriske og menneskets syndige natur, en association, der skulle vise sig at blive en af de mest sejlivede elementer i en kristen menneskeopfattelse. Det foregribes på sin vis allerede i Markusevangeliet $(5,12)$, hvor Jesus sender dæmonerne over i svinene. Ganske vist er dette netop en ydre relation; men for så vidt som svinet dermed forbindes med noget dæmonisk, åbner det metonymisk for, at noget dæmonisk omvendt forbindes med dyret. Djævelens manifestation som gedebuk er vel det mest prægnante eksempel på dette.

\section{Dyret i moderniteten}

Genesis gøres typisk ansvarlig for, at mennesket i den vestlige kultur har følt sig hævet over dyret og som følge deraf anvendt det til forskellige formål efter eget forgodtbefindende. ${ }^{23}$ Men faktisk var det også en udbredt opfattelse hos antikkens grækere og romere uafhængigt af en kristen tankegang. Til gengæld var der stor forskel på, hvordan man forstod forskellen mellem dyr og mennesker. For Aristoteles herskede der

21 Ganske vist fortsatte de kristne i det første århundrede med at ofre dyr, som det var jødisk skik; men allerede Paulus befalede dog de kristne ikke at spise kød fra offerdyr, 1 Kor 10, 28.

22 Dominikaneren Thomas Aquinas, der i Summa Theologica (2.1, kap. 4) udlagde betydningen af den jødiske offerpraksis i lyset af den kristne lære, kunne således også skrive, at den fandt sted "som et forvarsel om udgydelsen af Kristi blod og overfloden af Hans af hans næstekærlighed, hvormed han ofrede sig selv til Gud for os."

23 Thomas Aquinas var måske den middelalder-tænker, der klarest understregede menneskets ret til at behandle dyr efter eget behov, jf. Summa Theologica 2.2, kap. 2. Se i øvrigt Lasse Løvlund Toft i nærværende nummer af Religionsvidenskabeligt Tidsskrift m.h.t. kirkefædrenes syn på menneskenes herredømme over dyrene. 
ingen tvivl om værenshierarkiet. "Selv den mindste viden om det uendelige og guddommelige", som han sagde, var langt vigtigere for mennesket "end en omfattende viden om de dyr, der omgiver det" (Posterior Analytics 1.5, 644b31-645a4). Omvendt hævdede nyplatonikeren Porfyr, at dyrene på deres egne betingelser besad en veludviklet fornuft (De Abst. 3.7-11 = Porphyry 2017, 122 ff). For ham betød denne kendsgerning, at mennesket burde afholde sig fra at spise dyr (en opfattelse der i øvrigt bredte sig fra Indien til Persien i løbet af aksetiden). Bag denne afholdenhed lå pythagoræiske og orfiske forestillinger om metempsykosis og dermed en opfattelse af, at der ikke eksisterede en absolut grænse mellem menneskets og dyrets sjæle.

Der er altså tale om to modsatrettede synsmåder: menneskets uindskrænkede herredømme over dyrene på den ene side og dets opfattelse af et solidarisk fællesskab med dem på den anden. Ganske vist anføres der fra hver lejr rationelle argumenter for, i hvilken udstrækning dyrets mentale egenskaber kan eller ikke kan sammenlignes med menneskets; men det er vel at mærke grunde, der allerede er involveret i en menneskelig selvforståelse. Såvel ligheds- som forskelsaspekterne har deres reference i en fortolkningsafhængig livsform, der ikke kan tage til genmæle. Bestemmelsen af dyrenes væsen finder derfor altid sted fra et udgangspunkt, hvor mennesket allerede ser sig selv i relation til dem. Det er det, som den italienske filosof Giorgio Agamben har kaldt for den antropologiske maskine. Vi har brug for dyrene som et differentiale i produktionen af vores selvforståelse som mennesker. Et oplagt eksempel på dette er Ludwig Feuerbach, der definerer den menneskelige bevidsthed ud fra det modsætningsforhold til dyrene, at det kan betragte sig selv som art og begribe det uendelige (Feuerbach 2005, 37 f).

Generelt er det da også forskelstænkningen, der har domineret i den vestlige verden. Det berømteste eksempel er nok Descartes, der betragtede dyret som et automaton, en selvbevægende maskine uden egentlig bevidsthed, hvorfor han i videnskabens navn forsvarede vivisektion. En hunds skrig var ikke udtryk for en følelse af smerte, men snarere at sammenligne med hvinende tandhjul. En oplysningstænker som Kant begrundede menneskets værdighed ud fra den autonome fornuft, der netop adskilte det fra dyret, og Hegel fulgte trop med påpegningen af, at dyret var uden ånd, fordi det var afskåret fra en dialektisk selvbestemmelse. Opfattelsen af, at mennesket som et enestående åndsvæsen var hævet over naturen, stod ganske vist ikke uanfægtet. "Indbildskhed er vores naturlige og oprindelige sygdom", som Michel de Montaigne skrev i 1580, "Mennesket er den mest elendige og skrøbelige af alle skabninger og ikke desto mindre det stolteste". Efterfølgende spørger han (2006, 448 f [bog 2, kap. 21]): "Hvordan ved det, selv med sin forståelses styrke, hvilke hemmelige rørelser, der foregår i dyrenes indre? Ud fra hvilken sammenligning mellem dem og os udleder han den uforstandighed, han tilskriver dem?" På sin vis placerer Montaigne sig i samme position som Porfyr, for så vidt som han kritiserer tendensen til at undervurdere dyrenes evner. Men samtidig tilhører han også en anden tid, hvor fornuften ikke havde samme uanfægtelige status som blandt græske og romerske filosoffer. 
Ganske vist havde oplysningstænkningen i sidste halvdel af det 18. århundrede fremhævet den menneskelige fornufts autonomi og dermed undergravet kirkens forsøg på at fastholde en blind trosautoritet; men klassicismens og romantikkens tænkere, for hvem det drejede sig om at forsone ånd og natur, havde efterfølgende rettet fokus på følelserne som en ligeværdig del af den menneskelige natur. Bortset fra intellektuelle overvejelser over dyrets væsen ser vi også eksempler på, at det rent æstetisk associeres med den fornyede interesse for følelseslivet. Allerede i Kants optik adskilte følelsens tilbøjelighed sig fra fornuften ved at have sin rod i en dunkel (uoplyst) natur, og netop menneskets indre blev, som det i øvrigt var tradition i kristendommen, associeret med dyriske tilbøjeligheder. På Füsslis maleri Le Cauchemar (Mareridt) fra 1781 martres en sovende kvinde af en dæmon (maren), der sidder på hendes bryst; men vi ser også en hest (formentlig folkemytologiens helhest) stikke hovedet frem bag et forhæng ved kvindens leje. Det vil være oplagt at tolke forhænget som et dække for det mørke sjæledyb, Freud senere skulle kalde det ubevidste. Hesten er den dyrisk-erotiske kraft, der bryder igennem dydens forsvar og gør krav på kvindens krop og sjæl. Ifølge Freud gav det anonyme ids maskerede fantasier sig således ofte udtryk i dyreskikkelser, som hans berømte analyse Ulvemanden er et eksempel på (Freud 1984).

Igen gør den immanente transcendens sig gældende. Dyret er det manifeste, psykisk tilladelige udtryk for en skjult sammenhæng. Transcendensen har fået en indre dimension. Idéhistorisk har en overordnet rettethed mod Gud forskudt sig til en rettethed mod menneskets egen sjæl. Således var det gudstroen snarere end Gud selv, der optog tidens filosoffer (f.eks. Schleiermacher, der definerede troen som schlechthinnige Abhängigkeitsgefühl, følelsen af en absolut afhængighed). Såvel striden som forsoningen stod mellem ånd og kød, Gud og dyr, i mennesket selv. Den hierarkiske triade producerede stadig betydning, selvom man i en vis psykologisk forstand kan sige, at mennesket byttede plads med Gud som hierarkiets top. Den idiomatiske dualisme mellem det guddommeligt ophøjede og det dyrisk lave havde ikke mindst sin realitet som stridende kræfter i sjælen, uanset hvad prædikaterne konkret refererede til.

Men ét er de æstetiske, symbolske og metaforiske projektioner, der som hidtil rettes mod dyrene - noget andet er menneskets praktiske omgang med dem. Her er det herredømmeforholdet, ikke blot over dyrene, men over naturen i det hele taget, der primært gør sig gældende. Springer vi frem til vores egen samtid, er det netop denne antropocentriske exceptionalisme, der står for skud. Det gælder såvel et generelt filosofisk selvopgør som den aktuelle øko-kritiske diskurs.

Filosofien har længe været præget af et opgør med forestillingen om et autonomt subjekt, der skiller sig ud fra omverdenen ved at forholde sig refleksivt til den. En af dem, der gjorde en forskel i forrige århundredes mellemkrigsperiode, var Martin Heidegger, der udskiftede idealismens fornuftssubjekt med en i-verden-værende Dasein. At befinde sig i verden i en med-væren (Mitsein) med andre mennesker, jorden og tingene, er det, der 'stemmer' 24 den menneskelige bevidsthed, ikke den fornuft, der i sin abstraktionsevne ser sig hævet over de fysiske vilkår. I sit forsøg på at bestemme, 
hvad det vil sige at være i verden, opstiller Heidegger $(1983,263)$ en treleddet tese, der hævder, at stenen er 'verdensløs' (Weltlos), dyret er verdensfattigt (Weltarm), mens mennesket er verdensbyggende (Weltbildend). En uorganisk genstand som en sten er passivt til stede i omgivelserne og har derfor ikke en verden for sig. Dyret reagerer på omgivelserne og kan derfor tilgå verden; men da det ifølge Heidegger ikke kan forholde sig til det værende som noget værende, kan det ikke i egentlig forstand siges at have en verden. Det er bundet af de instinkter, der tjener til at opretholde dets eksistens og befinder sig således inden for det, han kalder en Enthemmungsring (1983, 383): ${ }^{25}$ en lukket kreds af de elementer, der både aktiverer og binder dyrets adfærd. I modsætning til dyret kan mennesket forholde sig til det værende som sådan, hvorved det i egentlig forstand har en verden for sig. I modsætning til dyret, for hvilket verden er åben inden for dets tilfangetagelse i omgivelserne, fremstår verden for mennesket som fundamental tillukkethed. Det står til mennesket selv at forme sin verden ud fra det mulighedsperspektiv, som til gengæld åbenbarer sig gennem den unikt menneskelige værenserfaring.

Selvom Heidegger tager afstand fra den traditionelle bevidsthedsfilosofi, der knytter den menneskelige selvforståelse til et principielt verdensuafhængigt subjekt, har han samtidig brug for at kigge dyret 'over skuldrende' i sin eksplikation af en menneskelig værensform. Ganske vist indrømmer han, at bestemmelsen af dyrets verdensfattige eksistens er set ud fra en menneskelig synsvinkel (1983, 394); men i den kontrast, som denne værensform danner til vores egen verdensformende natur, må vi ikke desto mindre sige, at den menneskelige verden er rigere, fordi den er givet ved Daseins forholden sig til sin egen Sein-können i det værende som værende. Dyrets objektive verdensfattighed følger således af, at det er fanget af sin egen organismes reaktion på stimulanser (egentlig: disinhibitorer) i omgivelserne.

Heideggers tese vedrørende dyret gentager i sin filosofiske refleksion forestillingen om dets immanente transcendens. Vi mennesker kan på den ene side sætte os i dyrets sted, fordi begge som muskuløse og sansende organismer kan tilgå verden; både dyr og mennesker har en oplevelse af, hvad det er at bevæge sig i retning af et mål, at undgå farer, at skjule sig og så videre. Men dyret kan ikke forholde sig til tingene som ting. Det rejser imidlertid et spørgsmål til, hvad det i det hele taget vil sige $i k k e$ at kunne forholde sig til noget som noget? Sagen er, at vi kun kan tænke det på vore egne betingelser. Heidegger reformulerer altså det transcendente aspekt ved dyret i den udstrækning, at han i forsøget på at begribe dets manglende forholden-sig-tilnoget-som-noget netop forholder sig til denne værensform som sådan. Det er rent logisk ensbetydende med, at han på forhånd er udelukket fra at begribe den.

Det er påfaldende, at Heidegger alt-overvejende refererer til insekter, herunder bier, i sin bestemmelse af dyrets værensform; men selv ud fra denne begrænsende præmis åbner der sig en sprække i det skel, han sætter op over for den menneskelige væren. Giorgio Agamben tager således fat i det aspekt af dyrets væsen, der består i, at det af sin egen instinktive natur drives hen imod (hin-zu) noget uden for sig selv, som

25 Se hertil Nicolai Krejberg Knudsen i nærværende nummer af Religionsvidenskabeligt Tidsskrift. 
Heidegger understreger. Derved opstår der en rystelse (Erschütterung) i dets væren (Heidegger 1983, 396), en brydning mellem dets hin-zu og weg-von (343). Det oplagte eksempel på dette paradoks, påpeger Agamben (2004, 60), er møllet, der tiltrækkes af den lyskilde, der risikerer at brænde det op. Men det samme eksempel er også et af de ældste symboler på unio mystica, nemlig som en illustration af mystikeren, der hengiver sig til en højere virkelighed uden for sig selv (ibid.). De forskelle, hvormed den antropologiske maskine skaber orden i verden, har således sin modsætning i den mystiske erfarings grænseløshed, ligesom loven og sproget har sin implicit konstitutive modsætning i lovløsheden og det nonverbale - med andre ord, de aspekter, vi tilskriver dyrenes verden. Pointen er, at den ene tilstand har sin betingelse i den anden. I den bestemmelse af dyrets egenskaber, hvormed vi samtidig hævder at adskille os fra dem, følger de med som en nødvendig implikation i vores eget væsen; deres natur følger med ind i vores kultur.

I sit værk L'animal qui donc je suis (Det dyr, som jeg således er) fremfører Jacques Derrida (2006) en pointe, der til trods for hans eget forsøg på at dekonstruere Agambens synsvinkel, ejer oplagte ligheder med den. Derrida $(2006,144)$ foretager ligeledes et radikalt opgør med antropocentrismen, som han kalder for carnophallocentrisme for at understrege den traditionelle filosofis maskuline dominans. Og i forsøget på at skaffe sig et blik udefra indleder han bogen med en henvisning til sin kat, der har fulgt ham med ud på badeværelset. Idet han skal til at gå i bad, fanger han kattens blik og oplever, at han skammer sig over sin nøgenhed $(2006,18)$. Med denne nøgenhed refererer han på den ene side til Genesis, hvor mennesket først bliver menneske - i modsætning til dyret - da dets nøgenhed antager en seksuel betydning. På den anden side bliver nøgenheden også til en afklædning af filosofien selv. I skamfølelsen indgår der en erkendelse af, at det europæiske menneske i sin selvoptagethed kun har set dyret, men ikke selv ladet sig se af det $(2006,31)$. Det er klart, at Derrida derfor må understrege, at han ikke blot taler om katten som et billede, men om en rigtig levende kat. Det er ikke desto mindre en problematisk pointe at fremføre for en litterær tænker, der altid har proklameret 'il n'y a pas de hors-texte', at der ikke gives noget uden for teksten! Således indvender Donna Haraway $(2008,21)$ også over for ham, at katten hurtigt forsvinder ud af billedet $\mathrm{i}$ hans forsøg på at komme til rette med sit eget jeg.

Hvorom alting er, peger både Agamben og Derrida på, at menneskets grænsedragning mellem sig selv og dyret ikke alene har med objektive forskelle at gøre, men med selve grænsedragningens betydning som grænsedragning. Det er denne forskelssætten, der for Derrida er ensbetydende med, at vi aldrig er samtidige med os selv. Jeget kan ikke positivt bestemme sig selv ud fra et bevidstgjort 'jeg er' (je suis), for så vidt som sproget (det franske sprog vel at mærke) afslører, at je suis fonetisk indeholder et je sui: 'jeg følger efter'. Men at mennesket netop følger efter dyret, såvel i skabelsens orden som i dets egen bevidsthed om sig selv, betyder samtidig for Derrida, at dyret følger efter mennesket, ja, at det endog indhenter det nøjagtigt ved den grænse, mennesket trækker omkring sig selv. Samme pointe gør sig gældende hos Agamben.

Det interessante er endvidere, at de begge relaterer denne grænsedragning til et begreb om Gud. For Derrida indtager dyret en plads i menneskets selvforståelse, som 
er analog til det, Jacques Lacan i relation til barnets mentale udvikling har kaldt for den Store Anden. I modsætning til den lille anden, som er barnets spejlbillede, er den Store Anden (betydningsgiveren, signifiant) i første omgang moderen og siden sprogligheden (hvorfor vi ikke for intet kalder vort sprog for et modersmål). Begge udgør en andethed, som kommer bevidstheden i forkøbet. Det samme gør dyret og befinder sig dermed i en semantisk position, hævder Derrida, der svarer til Gudsbegrebet. ${ }^{26}$ Tilsvarende hævder Agamben, at menneskets forhold til Gud afhænger af den dybere relation, hvormed det skelner mellem sig selv og dyret $(2004,16)$. Det, som både Derrida og Agamben, så vidt jeg kan se, giver udtryk for uden at sige det eksplicit, er, at der (måske universelt) i den menneskelige symboldannelse består en ofte underforstået symmetri mellem det guddommeliges og det dyriskes transcendens. Den akse, omkring hvilken forskellen indsættes, er immanensen, dyrs og menneskers med-hinanden-væren (Miteinandersein, med Heideggers begreb). Men ligesom mennesket er skabt i Guds billede, som det hedder i Genesis (Gen 1, 26-28; 5, 1-3), er det også formet i lighed med dyret. Idéhistorisk står det vestlige menneskets væren beskrevet i et mellemværende mellem Biblen og naturens bog. Det er ikke for ingenting, at Physiologos var det værk, der udover Biblen blev oversat til de fleste europæiske og mellemøstlige sprog.

Men den antropocentrisme, som har sin rod i den kristne exceptionalisme via dens sækularisering i oplysningstiden, er kommet under angreb blandt toneangivende filosoffer i det 20. århundrede. F.eks. satte Gilles Deleuze og Felix Guattari en afgørende tankebevægelse i gang, da de i deres berømte værk Tusind Plateauer (Mille Plateaux) talte om menneskets bliven-dyr (devenir-animal, 1999, 277 ff.). Således ville de erstatte axiomet om det menneskelige subjekts primaritet med et rhizom, et rodnet, af tilblivelsesmuligheder, der hele tiden bevæger sig mod 'molekylære' interaktioner med omgivelserne og andre livsvæsner. Menneskelivet er i deres optik drevet af begærsmaskiner og bevæger sig ad et immanent plan, hvor flugtlinjer fører det gennem skiftende plateauer af betydningsdannelse. Den religiøse forestilling om transcendens udgør en sådan flugtlinje, som skaber en fold (forestillingen om den anden verden), der folder ind over sig selv (livet i denne verden). Analogt udfolder mennesker under givne omstændigheder egenskaber, der i omgang eller lighed med dyret folder sig ind over den umiddelbare væren-menneske. Tankegangen, der berusede sig i afviklingen af oplysningens selvforpligtende rationalitet, skulle siden være med til at inspirere det, der i bred forstand går under betegnelsen øko-kritik (eco-criticism). Tim Ingold er et af hovednavnene inden for øko-antropologien, mens Donna Haraway, Rosi Braidotti, Carol Adams, Val Plumwood og Karan Barad tilhører det fagfelt, der gerne omtales som øko-feminisme. Inden for religionshistorien følger Aaron Gross trop (under inddragelse af Ingold, Derrida og Agamben) ved at rette fokus på dyret som et med-konstituerende subjekt i religiøst symbolunivers (Gross 2015, 114. 189).

26 For Derrida omfatter Den Store Anden således 'den ahumane konfiguration af gud og dyr ifølge alle de theo-zoomorfe muligheder, som i egentlig forstand konstituerer myter, religioner, afgudsdyrkelser og endda former for offer-praksis i de monoteismer, der hævder at bryde med afgudsdyrkelsen', jf. 2006, 180, min oversættelse.

Dyrenes betydning i religion og filosofi 29 
Tim Ingold (2011a, 109 f.; 2011b, 10 f.; 83 ff.) refererer dels til Heideggers begreb om wohnen (beboen) som kendetegnende for menneskets måde at være i - og forme verden på, dels til Deleuze og Guattaris fremstilling af interagerende livsprocessenes rhizomatiske karakter. Således er stammefolks animistiske relation til dyr, planter og omgivelser ifølge Ingold udtryk for en økologisk sensibilitet, en bæredygtig wohnen, som det er værd at lytte til (2011a, 42; 2011b, 9-13). Vi har ikke længere råd til at udvise den arrogance, der traditionelt har kendetegnet antropologiens objektiverende og bedrevidende fremstilling af eksotiske folkeslag. Vi bliver nødt til at indgå i en åben dialog om, hvordan vi interagerer med den verden, vi har tilfælles med andre livsvæsner.

En lignende optik, der også trækker på den decentraliserende immanens-tænkning hos Deleuze og Guattari, er det, man i bred forstand har kaldt for post-humanisme og

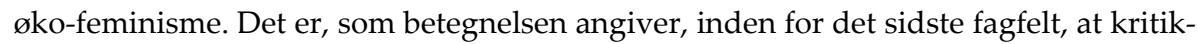
ken af antropocentrisme, exceptionalisme og speciesisme særligt kobles til et opgør med en maskulin samfundsdominans. Det jeg, der om sig selv tænker cogito ergo sum, er først og fremmest et maskulint jeg, hvilket også Derrida pointerer med sit begreb om carnophallocentrisme. Hos Haraway, Braidotti og Adams sammenlignes herredømmet over dyrene med herredømmet over kvinder, og en øko-kritisk dagsorden kobles således til en alliance med alle dem, der har måttet betale prisen for patriarkatets verdensorden. Jordkloden Gaia, der ikke tilfældigt bærer en kvindelig guddoms navn, må formildes ved en gennemgribende omstilling, hvis et menneskevenligt klima skal reddes.

Hos Donna Haraway får dyrene imidlertid ikke kun betydning som ofre for en rovdrift på naturens ressourcer, men også som "companion species", der inviterer til en "becoming with" (2008, 16 f; 19f), en deleuziansk udviklen-sig-sammen-med dyret (i hendes tilfælde en hund), som muliggør en "autre-mondialisation"; tilblivelsen af en anden verden inde fra verden selv. Det er imidlertid ikke en religiøs virkelighed, hun har i tankerne, men en ny verden med transformerede relationer, ikke blot mellem mennesker, men også og ikke mindst mellem mennesker og dyr. Selvom Haraway ikke ser sig selv som post-humanist, bidrager hun til en redefinition af mennesket som et livsvæsen, der radikalt bør vedgå sig sin symbiotiske sameksistens med andre 'companion species'. I den forbindelse henviser hun bl.a. til de bakterier, svampe og protister, "who are my maker" (s. 4). Den religiøse transcendens finder således sit ironiske modsvar i biologiens inverse dyb. Og ligesom det absolutte subjekt, Gud, er afviklet, må også forestillingen om et på forhånd defineret menneskesubjekt afskaffes. Al forankring finder sted i interaktion. "The partners [subjects] do not precede the meeting", som Haraway skriver; "species of all kinds, living or not, are consequent on a subject- and object-shaping dance of encounters" (2008, 4). Den norske filosof Arne Næss, der allerede i 1970'erne gav udtryk for en lignende tankegang, talte således for vigtigheden af "a close partnership with other forms of life" $(1973,96)$. Tankegangen ligger ikke langt fra Gross' $(2015,96)$ og Ingolds $(2011 a, 42)$ og synes at reproducere en moderne, omend hyperreflekteret, form for animisme.

"Today it seems interesting to me to go back to what I would call an animist conception of subjectivity", har således Guattari udtalt i et interview, "if need be through 
neurotic phenomena, religious rituals, aesthetic phenomena" (jf. Ramey 2016, 75). Der er grundlæggende tale om et ny-materialistisk opgør med den filosofiske idealisme: "How does subjectivity locate on the side of the subject and on the side of the object?" spørger Guattari (ibid.). Hermed hævder han implicit, at subjektivitet ikke begrænser sig til et ego, der ser sig selv $i$ forhold til et non-ego, men at subjekter findes overalt $i$ interaktive relationer; verden er besjælet af inter-subjektivitet i den forstand, at alt indvirker på alt. Den nye øko-kritiske bevidsthed, med afsæt i bl.a. Guattaris økosofi (2012 [1989]) og Næss' dybde-økologi (1973), hviler på denne grundlæggende anskuelse. Og kun den endegyldige afsked med antropocentrismens megalomani kan realisere den nødvendige nyorientering.

Med denne såkaldt 'ontologiske' vending (Holbraad \& Pedersen 2017), der kort sagt betyder, at verden betragtes som ensbetydende med menneskets noetiske og praktiske relationer til den, tildeles dyrene en ny opmærksomhed, som tilsyneladende vil gøre afbigt for den udnyttelse, de har været og stadig bliver udsat for. Det økokritiske forfatterkollektiv HARN27 skriver: "As anthropogenic change affects the more-than human world in innumerable ways, many argue that we must accept responsibility for the damage we have caused, and the debt we owe to non-human species” (HARN 2015, xvii). Det 'nye' menneske føler sig ikke længere skyldig over for Gud, men over for naturen og dyrene (Berry 2006, 7). Det strukturelle forhold går igen - med dyret som bærer af en intimt-immanent og spirituelt-materialistisk transcendens.

Jeg vil ud fra en idéhistorisk synsvinkel hævde, at det momentum, omsorgen for dyrevelfærd og bekymringen for den svindende biodiversitet har fået, bl.a. skyldes den betydning, som dyret i kølvandet på exceptionalisme-kritikken har antaget som en indre relation i mennesket. Samtidens filosofiske og post-humane diskurs vidner om, at det 'nye' menneske er parat til at se mere af dyret i sig selv. Det er ikke på mode at søge friheden i den abstrakte fornufts privilegium, men derimod i den nære, sensible interaktion med omgivelserne, vi deler med dyrene. Dertil er dog også at sige, at den post-humane interesse for Critical Animal Studies, Human-Animal Studies, Animal Rights, Zooanthropology og Zoopoetics, der både er seriøs og objektivt relevant, næppe skyldes, at mennesker i almindelighed er blevet venligere over for dyrene (dyreelskere har eksisteret til alle tider). Snarere skal grunden findes i en stigende frygt for, at omkostningerne ved at lade hånt om det øvrige liv på kloden efterhånden bliver for store. Senest er den corona-virus, der formentlig har spredt sig fra kinesiske dyremarkeder, et eksempel på nogle af de følelige konsekvenser, for slet ikke at tale om de danske minkfarme, der måtte aflive sine bestande i 2020 .

27 HARN står for Human Animal Research Network omfattende de australske forskere Madeleine Boyd, Matthew Chrulew, Chris Degeling, Agata Mrva-Montoya, Fiona Probyn-Rapsey, Nikki Sarvides og Dinesh Wadiwel. 
Dyreretsdiskursen, der daterer sig tilbage til 1800-tallet, ${ }^{28}$ har siden 1970 'erne haft et skelsættende omdrejningspunkt i Peter Singers berømte Animal Liberation (1975). Dog er man begyndt at rette en kritik mod præmisserne for hans syn på dyrs rettigheder. Argumentet er, at respekten for dyrenes ret til et liv uden menneskepåført lidelse ikke bør afhænge af, hvor meget de ligner mennesker (hvilket udgør en underliggende præmis hos Singer), men af en anerkendelse af alle livsvæsners ret til så vidt muligt at leve og udfolde sig på egne betingelser (Lindgren \& Öhman 2019, 1201). Det er en grundlæggende tanke om værdien af liv for livets egen skyld, som har vundet frem i forskellige diskurser fra filosofi til antropologi og diverse øko-kritiske diskurser. Fokus retter sig mod det, vi har til fælles med dyret: at være en levende organisme på jordkloden. Alt andet er dybest set af sekundær betydning. De symbolske energier, der engang forsynede et religiøst univers med dets moralske og fantasmatiske kraft, er i et sekulært, økologisk verdensbillede (uanset hvor spiritualiseret det konciperes i visse diskurser, se f.eks. Herbener 2015) suget ned i det sårbare og ængstelige liv, der er animalsk i sin grundsubstans. Klimakrisens trusselsscenarie er vor tids apokalyptiske vision.

\section{Agamben, dyret og det nøgne liv}

Agamben har med sit storstilede bog-projekt Homo Sacer i ni bind taget udgangspunkt i det romerske retsbegreb om homo sacer. Homo sacer betegner en person, der tildeles en 'hellig' (sacer) status som forbandet i den forstand, at vedkommende bortvises fra samfundsfællesskabet (2016, 89-92). Denne fordømmelse, hvormed loven inkluderer den pågældende person gennem eksklusion, som Agamben udtrykker det (dvs. at den dømte er genstand for den lov, der udstøder vedkommende), tydeliggør en grundlæggende distinktion, som på græsk kommer til udtryk i forskellen mellem zōe og bios (13 f). Zōē er livet som sådan, hvorfor både dyr og mennesker er zōon, et levende væsen. Men mennesket adskiller sig fra dyrene, som Aristoteles pointerer, ved at være et zōon politikon, et dyr, der forholder sig til sig selv som samfundsvæsen. Og netop menneskets liv som politēs (civis på latin), dvs. 'borger' i ordets antikke betydning, betegnes som bios. Bios er det liv, der kvalificeres af pligter og rettigheder inden for lovens rammer. Tilbage står zōē eller med Walter Benjamins begreb: det nøgne liv (Blosses Leben), hvis samfundsmæssige værdi afhænger af en yderligere kvalifikation. Det nøgne liv udgør således en farlig position, hvor loven endnu ikke eller ikke længere gælder. Såvel suverænen (Gud eller kejser), der fastsætter loven, som den, der fortaber sine rettigheder (dømt til helvede, landsforvisning eller status som fredløs), befinder sig i denne tilstand (Agamben 2016, $116 \mathrm{ff}$ ).

I værket Den højeste fattigdom (Homo Sacer IV/1) fremstiller Agamben (2011) franciskaner-ordenen som kendetegnet ved et liv, der ikke længere omfattes af curiaen (den katolske kirkes centralforvaltning). Paven anerkendte ordenen som en legitim

28 Den britiske dyreværnsorganisation Royal Society for the Prevention of Cruelty to Animals (RSPCA) blev således grundlagt i 1824 . 
brødremenighed under forudsætning af, at den frasagde sig alle lovformelige rettigheder. Brødrene måtte alene leve på den højeste fattigdoms betingelser - og fik i den henseende status som de dyr, de omgav sig med. ${ }^{29}$ Sagt med Deleuze og Guattari har gråbrødrene bevæget sig ud af det kirkeligt territorialiserede samfundsliv i en blivendyr, dvs. i en 'sammenpasning' (agencement) med naturens frie, gudsskabte væsner, ubundet af menneskenes love. For Agamben vidner dette liv - som mulighed - om det nøgne liv, som det er vigtigt at give agt på og værne om i en ny bio-politik. ${ }^{30}$

Det var denne position, jøderne i nazitiden befandt sig i og som førte til forsøget på at udslette dem. De blev ikke regnet som en værdig bios, en anerkendt race. Egentlig blev de slet ikke betragtet som mennesker, men som skadedyr, verden var bedre tjent med at være foruden.

Også flygtningen, der hverken kan sendes tilbage til sit hjemland eller få permanent opholdstilladelse i indrejselandet, befinder sig i det nøgne livs position, inkluderet af loven gennem eksklusion. Og endelig er også dyrene udtryk for det nøgne liv. Ganske vist omfattes de i mange samfund af dyreværnslove, men på betingelser, der typisk er formuleret på vegne af bios, nemlig de vilkår, vi ud fra en human og samfundsnyttig betragtning finder rimelige.

Der synes at tegne sig en enighed mellem Agamben, Derrida, Ingold, Gross, Braidotti og Haraway (for blot at nævne få repræsentanter for forskellige fagområder), som går på omsorgen for det nøgne, værgeløse liv. Det er her, Ingold (og mange andre antropologer med ham, heriblandt Rane Willerslev) drager en forbindelse til en animistisk sensibilitet og respekt for livet i sig selv.

Det liv, som får sit umælende udtryk i dyret, har tiltrukket sig en ny hellighed, en omsorgsfuldt medindraget animal sacer, der, som det hedder hos Lindgren og Öhman $(2019,1201)$, kunne antyde 'an animal turn'. Der ville således være tale om et korrektiv eller supplement til den antropocæne tidsalders 'human turn', hvilket samtidig synes at korrelere med antropologiens 'ontological turn', om end det må være op til andre end mig at skabe den fornødne klarhed over alle disse aktuelle vendinger, der nok kan forekomme mere proklamatoriske end diagnostiske. Alligevel vil jeg selv bidrage til festen og som sagt foreslå, at en ny, om end ofte implicit, hellighed, med dens objektfilosofiske implikationer af uudgrundelighed, henover de sidste årtier har knyttet sig til det liv, dyret og mennesket har til fælles.

\section{Konklusion}

Menneskets fascination af dyret begynder kulturhistorisk med hulemalerierne, hvor det - bortset fra håndaftryk, et par jægere og en shaman - er dyr af mange forskellige

29 Som Agamben skriver: "Hvis dyrene på sine ene side er menneskeliggjort og bliver 'brødre' ..., så er brødrene i modsat fald og i rettens øjne sidestillet med dyrene,' 2011, 176.

30 Dette synes at være i samklang med Rosi Braidottis zoe-centrerede egalitarisme, se Nicolai Krejberg Knudsen i nærværende nummer af Religionsvidenskabeligt Tidsskrift. 
slags, der dominerer på de europæiske, underjordiske klippevægge. Deres tavse udtryksfuldhed fortæller åbenlyst om den ekstraordinære - for ikke at sige hellige - betydning, den tids befolkninger (fra neanthalere til de aurginaciske og magdaleniske folk) tillagde dem. Men fascinationen fortsætter i animisme og totemisme, hvor planter og dyr kommer til at spille en fremtrædende rolle i kult og myte, både som beslægtede væsner og som repræsentationer af en guddommeligt livgivende - og undertiden destruktiv - kraft. Fremkomsten af mere differentierede samfund, der ernærede sig ved agerbrug og anvendelsen af husdyr, blev til gengæld ledsaget af symbolsystemer, der definerede en ny, hierarkisk værensorden. Dyrene fungerede som narrative mediatorer mellem gudernes og menneskenes verden, men i stigende grad med metaforisk og allegorisk betydning. Deres dobbelte natur som fremmede og familiære livsvæsner, svarende til en universelt fænomenologisk opfattelse af deres immanente transcendens, betød dog også, at de i vidt forskellige mytekomplekser optrådte som gudernes ledsagere og budbringere. Bortset fra deres interessante, men marginale videreførelse som apotropæiske stenfigurer på utallige bygningsværker fra middelalder til renæssance, udvandes dyrenes symbolske potentiale efterhånden mere eller mindre til rene moralske eksemplifikationer. Det interessante er dog stadig, at dyret $i$ det hele taget gøres til genstand for en betydningstilskrivning, der tjener til at kaste lys over den menneskelige verden og ikke mindst menneskets relation til en højere virkelighed. Fra dets relative skyggetilværelse i lyset af det kristne skabelseshierarki og senere det oplyste menneskes antropocentriske verdensorden er dyret således atter kommet til ære og værdighed som prægnant betydningsbærer i filosofi, antropologi og diverse øko-kritiske, post- og trans-humanistiske teoridannelser. Spørgsmålet er imidlertid, hvordan vi skal vurdere den alliance mellem den aktuelle, øko-sensible optagethed af livet-forlivets-egen-skyld og den revitaliserede interesse for en animistisk omverdensforståelse?

For mig at se har dyrene altid ansporet mennesket til at tænke noget andet end sig selv og sig selv som noget andet. De udgør et slags betydningsrelæ for omvekslingen af det synlige og usynlige, det nærværende og det fraværende, det konkrete og det abstrakte. Det er ikke svært at få øje på denne universelle betydningsressource i mange af de verserende antropologiske, neo-animistiske, øko-kritiske og ikke mindst øko-feministiske debatter. Dyret bliver genstand for en livsform, der viser bort fra en maskulin dominans; det bliver symbol for en dybde-økologisk samhørighed, der lægger afstand til det antropocentriske åndsbegreb. Det ændrer dog ikke på, at dyret samtidig forbliver et animal symbolicus. I en menneskelig fortolkningsverden er dyrene aldrig blot dyr, men som Derrida skriver: l'animot (enslydende med l'animaux, den franske flertalsform af 'dyr'). L'animot er det ord (mot), der træder i stedet for alle de væsner, som fra insekter til primater presses ind i samme kategori $(2006,11)$. Den antropologiske maskine producerer fortsat sine egne begreber, som Agamben påpeger. Dyret er aldrig kun den virkelige reference, men også og ikke mindst den symbolske genstand for et menneskeligt selvforhold. Det gælder såvel animismen som dens intellektuelle reproduktion i en moderne optik. Og det må nøgternt siges, at de konkrete, situationsbetingede symboldannelser, som den antropologiske feltforskning har beskrevet for 
os, ligger meget langt fra den systematiske, hyper-refleksive og abstrakte udformning, neo-animismen antager i nutidens øko-kritiske diskurs. Det menneskelige begrebshegemoni er lige så aktivt og i virkeligheden lige så antropocentrisk til stede som nogen sinde. Blot har der meldt sig en ny udfordring, et nyt grænseland, som skal indtages (selvfølgelig til klodens og fremtidens bedste!), nemlig den livsverden, der kommer til udtryk gennem de sagesløse dyr. Det er en anden verden, som vi er parate til også at gøre til vores. Spørgsmålet er om, carnophallocentrismen er død og begravet, eller om den blot har maskeret sig under andre, tilsyneladende mindre selvcentrerede strategier. Jeg tror det sidste.

Tilbage står en vigtig pointe, som også indbefatter vores symbolske og praktiske relationer til dyrene, nemlig opmærksomheden på det blotte liv, der ikke tjener andet formål end sin egen overlevelse, men som konstant udfordres af - om ikke ignoreres til fordel for - det kvalificerede, formålstjenstlige liv. Det handler både om marginaliserede mennesker og industrielle dyr. Og det handler om en alteritet, som uden for de overlevende religiøse trossystemer søger efter nye udtryk.

\section{LITTERATUR}

\section{Adams, Carol J.}

2010 The Sexual Politics of Meat, New York: Continuum International Public.

Agamben, Giorgio

2016 Homo Sacer: Den suveræne magt og det nøgne liv, oversat af Carsten Juhl, Aarhus: Forlaget Klim.

2004 The Open: Man and Animal, oversat af Kevin Attell, Stanford, California: Stanford University Press.

2011 Den højeste fattigdom: Klosteregler og livsform (Homo Sacer IV, 1), oversat af Lars Östman, Forlaget THP.

Alexander, Dominic

2008 Saints and animals in the Middle Ages, Woodbridge, UK \& Rochester, New York: Boydell Press.

Apuleius, Lucius

1950 The Golden Ass, oversat og kommenteret af Robert Graves, Middlesex, England \& Victoria: Australia: Penguin Books Ltd.

Barber, Richard

1992 Bestiary, Boydell \& Brewer GB.

Benveniste, Emile

1969 Le vocabulaire de institutions indo-européennes, vol. 1, Paris: Editions de Inuit.

Berry, Thomas

2006 "Prologue: Lonliness and Presence", in Paul Waldau \& Kimberly Patton, eds., A Communion of Subjects: Animals in Religion, Science, and Ethics, New York:

Columbia University Press, 5-10.

Blankenburg, Wera von 
1975 Heilige und Dämonische Tiere, Köln: Wienand Verlag [1943].

Boas, Franz

1917 "Folk-Tales of Salishan and Sahaptin Tribes", The American Folk-Lore Society, Bind 11, Victoria, Australia: Leopold Classic Library, 40-43 [1917].

Bonaventura

2002 Frans af Assisis liv: fortalt af Bonaventura, oversat af Johannes Jong, med introduktion af Lisbeth Mannerup Nielsen, København: Gyldendal.

Burkert, Walter

1983 Homo Necans: The Anthropology of Ancient Greek Sacrificial Ritual and -myth, oversat af Peter Bing, Berkeley, Los Angeles \& London: University of California Press.

Cassirer, Ernst

1955 The Philosophy of Symbolic Forms, bind 2: Mythical Thought, oversat af Ralph Manheim, New Haven \& London: Yale University Press.

Deleuze, Gilles \& Guattari, Felix

1999 A Thousand Plateaus, oversat af Brian Massumi, Minnesota: Bloomsbury Academic.

Derrida, Jacques

2006 L'animal que donc je suis, Galilée.

Descola, Philippe

2013 Beyond Nature and Culture, oversat af Janet Lloyd, Chicago: Chicago

University Press. https://doi.org/10.7208/chicago/9780226145006.001.0001

Evans, Edward Payson

1896 Animal Symbolism in Ecclesiastical Architecture, New York: Henry Holt.

1906 The criminal prosecution and capital punishment of animals, London: Heinemann.

Feuerbach, Ludwig A.

2005 Das Wesen des Christentums, Stuttgart: Reclam.

Foucault, Michel

1984 "Of Other Spaces: Heterotopias and Utopias", Architecture /Mouvement/ Continuité, 1-9.

Freud, Sigmund

1984 Ulvemanden, oversat af Lars Andersen \& Hanne Gesang, København: Hans Reitzels Forlag.

Friedmann, Herbert

1980 A bestiary for Saint Jerome: animal symbolism in European religious art, Washington, D.C.: Smithsonian Institution Press.

Gross, Aaron S.

2015 The Question of the Animal and Religion: Theoretical Stakes, Practical Implications, Columbia: Columbia University Press. https://doi.org/10.7312/gros16750

Guattari, Felix

2012 Three ecologies, London: Continuum.

Hallowell, A.I. 
1960 "Objiwa Ontology, behavior and world view", in S. Diamond, ed., Culture in history: essays in honor of Paul Radin, New York: Columbia University Press, 1952.

Haraway, Donna

2008 When Species Meet, Posthumanities 3, Minneapolis: Minnesota Press.

\section{HARN}

2015 M. Boyd et al., "Introduction", in Animals in the Anthropocene: Critical perspectives on non-human futures, xii-xiv.

Heidegger, Martin

1983 Die Grundbegriffe der Metaphysik, Vittorio Klostermann: Frankfurt a.M.

Herbener, Jens André P.

2015 Naturen er hellig: Klimakatastrofe og religion, København: Informations Forlag.

Holbraad, Martin \& Morten Axel Pedersen

2017 The ontological turn: An anthropological exposition, Cambridge: Cambridge University Press. https://doi.org/10.1017/9781316218907

Ingold, Tim

2011a The Perception of the Environment: Essays on Livelihood, Dwelling and Skill, London \& New York: Routledge.

2011b Being Alive: Essays on Movement, Knowledge and Description, London \& New York: Routledge. https://doi.org/10.4324/9780203818336

2015 “The Correspondence of Lives", forelæsning som led i programmet "Nature and Culture as False Dichotomy: Approaches to an integrated view of human life from biological and anthropological perspectives", Seminar Series at the University of Konstanz, arrangeret af Dr. Raúl Acosta-García, Department of History and Sociology, University of Konstanz:

http://allegralaboratory.net/tim-ingold-on-the-correspondence-of-lives/).

Lindgren, Nicklas \& Öhman, Johan

2019 "A posthuman approach to human-animal relationships: advocating critical pluralism", Environmental Research 25/8, 1200-1215.

https://doi.org/10.1080/13504622.2018.1450848

McEvilley, Thomas

2002 The Shape of Ancient Thought, New York: Allworth Press.

Monberg, Torben

1966 The Religion of Bellona Island: A Study of the Place of Beliefs and Rites in the Social Life of Pre-Christian Bellona, København: Nationalmuseets udgivelser.

Montaigne, Michel de

2006 "An apology for Raymond Sebond", Essays of Montaigne, Complete, Project Gutenberg, E-bog

Næss, Arne

1973 "The shallow and the deep, long-range ecology movement", Inquiry 16, 95100. https://doi.org/10.1080/00201747308601682

Peled, Ilan

2019 "Categorization and Hierarchy. Animals and their Relations to Gods, Humans 
and Things in the Hittite World", in: R. Mattila, S. Ito \& S. Fink, eds., Animals and their Relations to Gods, Humans and Things in the Ancient World, Wiesbaden: Springer, 79-94. https://doi.org/10.1007/978-3-658-24388-3_5

Physiologos: A Medieval Book of Nature Lore

1979 oversat af Michael J. Curley, London \& Chicago: The University of Chicago Press.

Podemann Sørensen, Jørgen, ed.

1988 Skriftløse Folks Religioner, København: GADs Forlag [= SFR].

Porphyry

2017 Porphyry's On the Abstinence From Animal Food, red. og oversat af David Christopher Lane, MSAC Philosophy Group.

Ramey, Joshua

2016 “Deleuze and Guattari's Machinic Animism”, in: Lindsay Powell-Jones \& F. LeRon Shults , eds., Deleuze and the Schizoanalysis of Religion, 75-94.

Robertson Smith, William

1972 Lectures on the Religion of the Semites: The Fundamental Institutions, New York: Schocken Books [1889].

Salter, David

2001 Holy and Noble Beasts: Encounters with Animals in Medieval Literature, D.S. Brewer.

Scott, Colin

1989 "Knowledge Construction among Cree hunters: metaphors and literal understanding", Journal de la Société des Américanistes 75, 193-208. https://doi.org/10.3406/jsa.1989.1349

Singer, Peter

1975 Animal Liberation: A New Ethics for Our Treatment of Animals, New York: HarperCollins.

Tapper, Richard

1988 "Animality, humanity, morality, society", in: Tim Ingold, ed., What is an animal?, London: Unwin Hyman, 47-62.

Viveiros de Castro, Eduardo

2004 "Perspectical Anthropology and the Method of Controlled Equivocation", Tipití 2 (1), 3-22.

2015 The Relative Native: Essays on Indigenous Conceptual Worlds, Chicago: The Chicago University Press.

Watanabe, Hitoshi

1994 "The Animal Cult of the Northern Hunter-Gatheres: Patterns and Their Ecological Implications", in: Takashi Irimoto \& Takako Yamada, eds., Circumpolar Religion and Ecology, 47-67.

Willerslev, Rane

2007 Soul Hunters: Hunting, Animism, and Personhood Among The Siberian Yukaghirs, Berkely, Los Angeles \& London: University of California Press. https://doi.org/10.1525/9780520941007 
Wittgenstein, Ludwig

2009 Filosofiske Undersøgelser, oversat af Peter Seeberg, København: Munksgaard.

Lars Albinus, lektor, dr. theol. Afdeling for Religionsvidenskab, Aarhus Universitet 